\title{
Depictions of archery in Sassanian silver plates and their relationship to warfare
}

\author{
Kaveh FARROKH ${ }^{*}$ (D) , Manouchehr Moshtagh KHORASANI2 (D) \& Bede DWYER ${ }^{3}$ \\ ${ }^{1}$ University of British Columbia (Canada) \\ 2 Razmafzar Organization (Germany) \\ ${ }^{3}$ Razmafzar Organization (Australia) \\ Recepción: 19/02/2018; Aceptación: 29/08/2018; Publicación: 10/09/2018.
}

\begin{abstract}
This article provides an examination of archery techniques, such as drawing techniques of the bowstring, the method of grasping the bow grip and placing the arrow, and their relationship to warfare as depicted on 22 Sassanian and early post-Sassanian silver plates. These plates provide useful information on Sassanian archery equipment and techniques. These plates can be categorized into the following categories: (a) foot archery, (b) horse archery, c) dromedary archery and (d) elephant archery. All plates examined in this study depicting these categories are in a hunting milieu. The largest proportion of plates pertain to horse archery which in turn can be classified into four combat subsets: forward-facing horse archery, the backward-firing Parthian shot, horse archery with stirrups, and horse archery while appearing to ride backwards.

Keywords: Martial arts; Persian martial arts; historical martial arts; Sassanian bow; archery; composite bow.
\end{abstract}

\section{Representaciones de tiro con arco en platos sasánidas de plata y su relación con la guerra Resumen}

En este artículo se examinan las técnicas de tiro con arco, tales como el anclaje de la cuerda del arco, la forma de agarrar el arco y la colocación de la flecha, y su relación con la guerra, tal y como muestran 22 platos de plata del periodo sasánida y post-sasánida temprano. Estos platos aportan información útil sobre el equipamiento y las técnicas de tiro con arco sasánida. Los platos pueden categorizarse en los siguientes tipos: (a) tiro con arco de pie, (b) tiro con arco a caballo, c) tiro con arco sobre dromedario y (d) tiro con arco sobre elefante. Todos los platos examinados en este trabajo muestran escenas de caza. El mayor número de platos corresponden a tiro con arco a caballo, que a su vez se puede clasificar en cuatro subgrupos: tiro mirando hacia adelante, tiro parto hacia atrás, tiro con estribos y tiro en aparente retroceso.

Palabras clave: Artes marciales; artes marciales persas; artes marciales históricas; arco sasánida; tiro con arco; arco compuesto.

\section{Representações de tiro com arco em pratos sassânidas de prata e a sua relação com a guerra Resumo}

Neste artigo examinam-se as técnicas de tiro com arco, tais como encaixar os dedos na corda, forma de agarrar o arco e a colocação da flecha, e a sua relação com a guerra, como mostram os 22 pratos de prata do período sassânico e póssassânico analisados. Estes pratos dão-nos informações úteis sobre o equipamento e as técnicas de tiro com arco sassânico. Os pratos podem categorizar-se nos seguintes tipos: (a) tiro com arco de pé; (b) tiro com arco a cavalo; (c) tiro com arco sobre dromedário; e (d) tiro com arco sobre elefante. Todos os pratos examinados neste trabalho mostram cenas de caça. 0 maior número de pratos examinados corresponde a tiro com arco a cavalo, que, por sua vez, se podem classificar em quatro subgrupos: tiro olhando para a frente, tiro parta para trás, tiro com estribos e tiro com aparente retrocesso.

Palavras-chave: Artes marciais; artes marciais persas; artes marciais históricas; arco sasánico; tiro com arco; arco composto.

\section{Introduction}

This paper examines a total of 22 Sassanian and early post-Sassanian metalwork plates depicting archery motifs in 12 museums and museum exhibits (Hermitage Museum, St. Petersburg; Freer and Sackler Galleries of the Smithsonian Institution, Washington, D.C.; Arthur M. Sackler Gallery Exhibit in Washington, D.C.; The Metropolitan Museum of Art, New York; Bibliotheque Nationale, Paris; Cleveland Museum of Art; Iran Bastan Museum, Tehran; Azerbaijan Museum, Tabriz; Los Angeles County Museum of Art; British Museum; The Cincinnati Art Museum Exhibition;

*E-mail: manuvera@aol.com 
Miho Museum, Japan; Museum for Islamische Kunst, Berlin), two auction houses (Sotheby's Antiquities Auction; Christie's) and a recently discovered plate displayed in the Sasanika.org site (Sasanika.org, 2014). The plates examined are categorized into four broad categories: (1) foot archery, (1) horse archery, (3) dromedary archery and (4) elephant archery. Most plates exhibit horse archery $(n=19)$, with the remaining samples distributed in plates depicting foot archery $(n=1)$, elephant archery $(n=1)$, and dromedary archery $(n=1)$. The large proportion of plates depicting horse archery is possibly a reflection of the importance of cavalry archery and equestrian culture in the Sassanian Spah (army) in general. Nevertheless, the lower numbers of available plates depicting other archery forms (foot archery, etc.) certainly does not diminish the military significance of these methods to the Spah, as will be noted in the discussions to follow. This situation warrants further excavations for Sassanian artifacts (esp. metalwork plates) in Iran and surrounding environs once part of the Sassanian empire (i.e. Afghanistan, Iraq, the southern Caucasus, etc.), Central Asia, Eurasia and Russia. ${ }^{1}$

All plates on archery depict a warrior-king and/or nobleman engaged in the hunt. The royal hunt was a critical venue for military training (on horseback and dismounted) especially in the use of bows, lances, javelins, and swords. The hunt was the Sassanian warrior's arena for testing his combat skills, bravery and physical resilience against beasts, the same skills required when combating formidable foes such as Romano-Byzantines or Turco-Hephthalites on the battlefield. The same battlefield weapons of archery, lances/spears, and swords used against prey were deployed against enemy warriors in battle. The hunt was in a sense, an arena for combat training. Despite the fall of the Sassanians to the Arab-Muslim invasions of the $7^{\text {th }}$ century CE, Iran's preIslamic hunter-warrior archetype was to survive into the post-Islamic era with characters such as Rostam and Garshasp being preserved in the Shahname and Garshaspname epics respectively (Hanaway Jr., 1971, p. 27). After the fall of Sassanian Empire, the Sassanian cavalry and warriors were highly sought after as extremely well-trained fighters. Additionally, they influenced the Arab Muslim culture by following a set of ethical and moral standards due to the extensive reforms introduced by Anushirwan and under the early Muslims, āzädegi shaped the core of the virtues and social practices subsumed under the name futuvva. The warrior land-holding āzādān were comprised of diverse groups, such as marzbānān, dahgānān (village-owning knights), and asbarān. These nobles, who were mounted warriors, seemed to have an authoritative impact on the "Persianization" of the Arab Bedouin culture also known as javānmardi (Zakeri, 1995, pp. 9-10). Sassanian warriors used hunting as one of their major way of training for warfare. According to Hanaway (1971, pp. 22-27), the Iranian martial milieu for the hunt had three facets: (1) the hunt as an arena to train for warfare (2) a domain for physical action, and (3) the opportunity for the display of ruthlessness. In this martial venue the hunter against prey is parallel to the warrior against dangerous adversary during battle. As further averred by Hanaway (1971, p.26):

...Hunting and war...resembled each other strongly in practice...required bravery, strength and skill...dangerous activities involving risk to both the hunter and the warrior. In both, the prey, human or animal, was pursued, eventually to be caught and killed. The techniques were similar and the weapons were the same, and in each case large numbers of men and horses were involved.

\footnotetext{
1 It might be argued that the archery scenes are not really depictions of archery combat. However, the argument is justified only if the same techniques were not used in both. However, it is widely admitted that the great formal hunts on horseback practiced in Eurasia were designed to enhance the prestige of the ruler at the same time as demonstrating military maneuvers and individual combat skills of the participants. "Of equal importance, war and the hunt are bracketed together, implying that they were inextricably linked in the minds of the Sassanid ruling elite" (Allsen, 2006, p. 209). The skills used in hunting from hides and stalking as practiced by modern bow hunters are not military skills, though they do improve one's skill in shooting. The bows used are lighter than those used in warfare. The great hunts of the Persian kings were designed like those of the later Mongols as training exercises. The skill of being able to aim and shoot at close range from horseback is the same whether the target is a lion or another soldier. What is important is that this close range encounter is what can happen on the battlefield. Horse archers can rapidly come to close range and if his bow is in his hand then it is the weapon he needs to know how to use.
} 
Post-Sassanian New Persian literature makes the linkage between the hunt and warfare clear and explicit. Addressing Massoud of Ghazna (r. 1031-1041 CE), Farrokhi-Sistani (1957) stated the following:

Since hunting to some extent resembles war, out of passion for battle when you are resting from war your thoughts turn to hunting ... (p. 77)

Sometimes your sword raises dust from the enemy's head; sometimes your arrow takes vengeance on a lion's breast ... On Hunting day it matters not to you if it be a fox or a lion: In battle it matters not to you if to be foot soldiers or horsemen ... (p. 79)

On the day of battle you take every king, On hunting day you take every lion... (p. 152)

The hunt, much as among the Mongols, Turks and Chinese, was in essence the Iranian military equivalent of a "live fire" exercise, as noted again in post-Sassanian New Persian literature, such as Saad-Salman (c.1121):

You are victorious, a king, a Khosrow, a Lord ... a city-conquering general and a lion-hunting king... (Saad-Salman, 1961, p. 193).

You are a King-hunter and when there are no kings left, Of necessity you hunt lion. (SaadSalman, 1961, p. 223). ${ }^{2}$

For the importance of archery in Iranian military tradition see Khorasani (2012).

\section{Analysis of archery techniques of Sassanian plates}

It is important to emphasize at this stage that we are writing an article on archery and military information with restraints of space and time. We are not writing an article on the identification and authentication of the silver plates. Although we take reasonable measures to rank the objects by their reliability as sources, we are not making definitive analyses on the origin and provenance of the objects themselves. The challenges posed by forgeries have been discussed by Gunter and Jett $(1992$, pp. 15, 20). None of the Sassanian objects discussed in this study have been cited as possible forgeries by Gunter and Jett who analyzed two objects (a plate with an eagle emblem and a bust of king) housed in the Freer and Sackler gallery as possible forgeries (pp. 230238). No other studies to date have yet surfaced questioning the items analyzed in this study as possible forgeries. It is also important to note that stylistic differences between typical Sassanian arts and outliers (items that differ in artistic style) are insufficient as criteria for classifying an item as a forgery ${ }^{3}$. Investigating artwork can be very misleading and tricky. The absence of certain features of a weapon and its related techniques such as archery methods depicted in Sassanian art can be due to the fact that artisans working for the Sassanian court followed certain artistic conventions and models. Some of the Sassanian plates examined are of post Sassanian origin as between certain artistic conventions and models, there are different features which identify a Sassanian plate as a late one. The dating of these plates is relevant to establish when techniques

2 Moezzi (1940, p. 222) corroborates Saad-Salman by asserting that "...You be a lion and all your enemies be prey".

${ }^{3}$ A more recent study by Skupniewicz (2015) for example has suggested that a Sassanian plate housed in the Azerbaijan museum of Tabriz is a modern forgery due to the differences of its stylistic features with mainstream Sassanian arts, however as noted by Dr. Gholamreza Karamian (Tehran Azad University, Archaeology department) the item at the Azerbaijan Museum in Tabriz needs to be (a) scientifically examined by electronic-dating instruments (notably the XRF [X-ray fluorescence] technique to determine metallurgy of the plate in order to compare with the metallurgy with other contemporaneous Sassanian metal plates) and (2) analyzed in person at the Azerbaijan Museum by archaeologists and art historians in the field of Sassanian studies/militaria) (Personal communication, July 27, 2018; Farrokh \& Karamian "The Azerbaijan Museum plate: a forgery or an outlier in Sassanian arts?" manuscript in preparation). In addition, there are examples of wide stylistic variances with respect to Iranian arts across a wide temporal span. An example of this was the find in Mskhetia, Georgia in early 2000 of winged lion dated to the $17^{\text {th }}$ century CE but styled on pre-Islamic Iranian arts and written with in new Persian script in a style different from mainstream Persian calligraphy (Farrokh, 2009, pp. 455-492). 
were practiced and how this relates to historical incidents. There are different features which identify a Sassanian plate as a late one:

(1) The frontality of the king's face is a rare feature in Sassanian sculpture and in the other silver plates. Normally the king's face on early Sassanian plates is shown in profile with his eyebrows, eye, and ear exhibited en face as is the case on the Sassanian silver plate kept in the Tenri Sankouban Museum in Nara, Japan (Tanabe, 1987, p. 81). This frontal depiction of the face is consistent with the late Sassanian and post Sassanian plates as can be observed in the silver plate of Khosrow II from the 7th century kept in the Hermitage Museum, a post-Sassanian silver plate from the Hermitage Museum attributed to the $7^{\text {th }}$ or early $8^{\text {th }}$ century and a post-Sassanian silver plate sold in the Sotheby's auction attributed to the $8^{\text {th }}$ century. However, a plate from MET attributed to the 5th century shows the face of the king in a halfway position between frontality and profile see the Sassanian silver plate attributed to the 5th century from the MET Museum. Note that this marginally three-quarter view is still a long way from the rotund facial frontality seen in the hunting scenes at Taq-e Bostan.

(2) The position of the drawing hand in earlier pieces is higher than the late pieces. For the position of the lower drawing hand in late pieces see the silver plate of Khosrow II from the 7th century kept in the Hermitage Museum, a post-Sassanian silver plate from the Hermitage Museum attributed to the $7^{\text {th }}$ or early $8^{\text {th }}$ century and a post-Sassanian silver plate sold in the Sotheby's auction attributed to the $8^{\text {th }}$ century.

(3) The third factor is that in later pieces both the arrow and the bowstring are clearly shown such as the silver plate of Khosrow II from the 7th century kept in the Hermitage Museum, a postSassanian silver plate from the Hermitage Museum attributed to the $7^{\text {th }}$ or early $8^{\text {th }}$ century and a post-Sassanian silver plate sold in the Sotheby's auction attributed to the $8^{\text {th }}$ century whereas in older silver plates, they are sketched with scratches in the metal.

(4) Fourth, instead of trousers, the king appears to be wearing leggings covering the calves over mail chausses which is the case in the silver plate of Khosrow II from the 7th century kept in the Hermitage Museum. This is a very unusual feature as kings did not wear armor when hunting. In a post-Sassanian silver plate from the Hermitage Museum attributed to the $7^{\text {th }}$ or early $8^{\text {th }}$ century the king appears to be wearing boots. Only in a post-Sassanian silver plate sold in the Sotheby's auction attributed to the $8^{\text {th }}$ century, the king appears to be wearing trousers.

(5) The fifth feature is that in later pieces, the feet are not turned down as much as in earlier silver plates and sculpture. The foot position is significant because it is either halfway (see the silver plate of Khosrow II from the 7th century kept in the Hermitage Museum) between the early depictions, characteristic of riding without stirrups (see a silver plate attributed to Shapur II from the Hermitage Museum), and the later horizontal position, characteristic of using stirrups (see a post-Sassanian silver plate sold in the Sotheby's auction attributed to the $8^{\text {th }}$ century). In one piece, the stirrups are clearly drawn (see a post-Sassanian silver plate from the Hermitage Museum attributed to the $7^{\text {th }}$ or early $8^{\text {th }}$ century). One should note that the pre-stirrup foot position was depicted with stirrups in later Soghdian art at Pianjikent showing a degree of artistic conservatism, but there are no cases in plates considered to be Sassanian where this occurs in reverse. That is to say that the post-stirrup foot position cannot be seen in any datable Sassanian silver plates.

(6) Finally, the straps supporting the quiver are vertical and misunderstood in later pieces and not the same as older versions. When detail is shown in both the rock reliefs and the silver plates, the quiver is usually suspended by three straps from a waist belt, one at each corner and one in the middle. ${ }^{4}$ This is very clear in the MET plate attributed to the late $5^{\text {th }}$ or early $6^{\text {th }}$. In the silver plate of Khosrow II from the 7th century kept in the Hermitage Museum, the quiver suspension

\footnotetext{
${ }^{4}$ Note that the obscured quiver suspension of the Pur-e Vahman plate has little relation to the Khosrow statue because they are two different types of quiver. This is much more significant than whether they are vertically suspended from rings or diagonally suspended from lappets. Judging from the angle and the exposed part of the arrows, the Pur-e Vahman quiver is more like Umayyad and Song Dynasty open quivers than either of the two Sasanian examples.
} 
and the sword belt appear confused with the quiver belt connected directly to the quiver and partially attached to the sword belt.

\section{Sassanian archery methods}

Archery was a highly valued combat arm in the armies of ancient Iran with its seminal role praised in adeptness in the Tir-Yasht (Khordeh Avesta, 1936) and Menog e Xrad (1913). Ancient Iranian adeptness in archery skills has been cited by Classical sources such as Herodotus (1972, I, p. 136), Strabo (1960) and Procopius of Caesarea (1914, I, p. 18). As noted by Ammianus Marcellinus (1996, XV, I, p. 13), Iranian archery was an "... art that nation has always been most skillful from the cradle". Regarding the archery method of Sassanians which are also depicted on Sassanian silver plates some important points need to be made. There are two major considerations regarding the Sassanian draw: (a) whether Sassanians used thumb draw or a variety of finger draw and (b) whether Sassanians placed the arrow on the right side or the left side of the bow grip. As we know when using a thumb ring and the thumb draw, the arrow is placed on the right side of the bow and this is an Asian tradition which can be observed in many countries in Asia, West Asia and Middle East. When using the Mediterranean finger draw for pulling a European longbow, the arrow is placed on the left side of the bow for a right-handed archer holding the bow in his left hand. Now there are different opinions on the Sassanian draw. Some state that they should have used a variety of thumb draw, meaning that the thumb was holding the string and the middle and ring fingers were curled on the thumb making a lock and the index finger was extended to keep the arrow against the bow. Others state that they should have used a finger draw by extending their index finger to keep the arrow in place and pull the bowstring by using the middle and ring fingers. The thumb could be curled on the middle and ring fingers or it can also be extended. In this method, the arrow can be placed on the left side or the right side of the bow grip. There is no written evidence in Europe of placing the arrow on the thumb side of the bow was common or even known. On the other hand, all surviving written instructions in England and America clearly indicate that the arrow must pass over the knuckle of the index finger of the bow hand." Mediaeval illustrations showing the contrary often have indications that arrow placement was conditioned on artistic requirements for symmetry rather than accurate representation or was affected by the order in which components were drawn. ${ }^{5}$

Although the former method, namely two fingers over the thumb method works and is similar to a historical style used by Ishi, the last Yana Indian in the early $20^{\text {th }}$ century (Pope, 1918, p. $120)$, it has no clear advantages over the regular thumb draw while being slower to release and weaker with heavy bows. The question arises if the regular thumb draw had been known to Sassanians, why wouldn't they have used that regular thumb draw. The following facts should be taken into consideration:

(a) The 8th century Arab manuals did not record such a draw. It must be remembered that the manuals did record a variant of the Sassanian draw as the Slavic draw (Șaqāliba) with the three

\footnotetext{
${ }^{5}$ It might be argued that we have failed to understand that the arrow could be placed on either side of the bow when using the so-called Mediterranean draw and suggests that the best evidence of this are the many European works of art which have the arrow on the right side of the bow. However, we would like to stress that the problem with this statement is that a brief look at many mediaeval illustrations from Europe shows that the side of the bow that an arrow is shown on has more to do with artistic choices than a desire for an exact representation. In European book illustrations, it is not uncommon to see that archers shooting to the left and those shooting towards the right have arrows on the same side of the bow as faces the viewer rather than the side that one would expect if they followed a consistent pattern of having the arrow on one side or the other. No European manual of archery has a recommendation for shooting on the thumb side of the bow and many have comments about how this is not even possible. One of the authors has demonstrated that both systems are possible with the proviso that it is how you are taught to shoot that determines which works the best. Aiming takes place in the brain and it gets used to doing things one way or the other. Practically it is clear that the two finger release allows the index finger to hold the arrow against the right side of the bow, but no Sasanian depictions show the index finger close to the arrow. The authors have actively evaluated the likelihood of the arrows ending up on the right side of the bow in fact rather than in the accident of depiction. It is possible and can be effective, but it is not supported by the evidence.
} 
lower fingers instead of the middle two (Faris \& Elmer, 1945, pp. 43-45). It should also be noted that in actually shooting with the two middle fingers, it is not uncommon for the little finger to curl somewhat, especially with a heavy bow. The Arab manuals give reference to a draw where the index finger is straight and the lower fingers pull the string. It is only one finger extended from one variety of the Sassanian draw. It is called Saqāliba or Slavic. It is doubtful whether the Arab furusiyya writers had much experience of the Slavic archery tradition. Without evidence that the Slavs in Byzantine service who deserted or were captured were archers, rather than the javelin throwers that the Byzantines record (Strategikon), there is no way to say the Arabs "definitely" knew anything about Slavic archery (the Strategikon states that the Slavs used wooden bows and short poisoned arrows). Compare the section on Greek archery in Arab Archery which describes a technique unknown in Greek literature. ${ }^{6}$ The Slavs that the western Arab writers were referring to were the ghulams of Ummayad Caliphate of Cordoba. Their training would have entirely eliminated any native archery traditions. On page 96 of Arab Archery (Faris \& Elmer, 1945), the authors note that the Slavs use silk bowstrings. This also indicates he is not talking about native Slavic archery. If the Umayyad refugees brought military trainers with them from Syria, they might also have brought late Sassanian archery techniques with them too. The Abbasids, with their Khorasani soldiers may have replaced this with an Eastern Iranian tradition of thumb ring use. Some early Arab geographers also used the term Saqāliba for tribes north of the Khazars (Sinor, 1990, p. 236) which covered several different cultural groups. We should note that the Arabs referred to the Sassanians as the Kisras after Khosrow rather than the Sassanians after Sassan. The important question is where the eighth century Arabs would have encountered the Slavs at all. It should be noted that the Arab authors differentiate between the lock of Bahram and the lock of Kisra (Chosroes or Khosrow) (Faris \& Elmer, 1945, p. 43; Latham \& Paterson, 1970, p. 53). However, like the Persian manuscripts, the actual lock or grasp in some cases varies. This suggests that the names were assigned to different locks at different times. What can be said for certain was that they were different locks.

(b) The Taq-e Bostan figure of the king shooting clearly shows the lower part of the string disappearing between the little and middle fingers of the drawing hand (Ghirshman, 1962, pp. 194-198 Pl. 237). The little finger is slightly curled and not extended. Despite some attempts to say that the vertical palm could be an indication of a thumb draw, in almost all verifiable cases it represents a finger draw.

(c) The silver plates usually show two versions of the drawing hand either with a vertical palm with extended index and little fingers or a vertical hand with an extended index finger alone. Both versions of the drawing hand can be observed on Sassanian silver plates: a) the index finger is extended such as in the $5^{\text {th }}$ century CE metalwork plate of Pirouz hunting on foot (Hermitage, Inv.S-216), the $4^{\text {th }}$ century CE metalwork plate of Shapur III hunting boar (Hermitage Museum, St. Petersburg), the 4-5 th centuries CE Sassanian silver gilt metalwork plate of a Sassanian king hunting rams (Arthur M. Sackler Gallery Exhibit in Washington, DC), 4th century CE silver-gilt plate of a Sassanian king on an ostrich hunt (Sasanika.org), $4^{\text {th }}$ or $6^{\text {th }}-7^{\text {th }}$ centuries CE silver gilt plate of a king hunting deer and various prey (LACMA-Los Angeles County Museum of Art), 7th century CE Sassanian silver gilt metalwork plate of king hunting gazelles (Arthur M. Sackler Gallery Exhibit in Washington, DC), the of $7^{\text {th }}$ century CE gilded silver metalwork dish of Yazdgerd III on the hunt (Bibliotheque Nationale, Paris), the early $7^{\text {th }}$ century CE Sassanian gilt silver dish of Khosrow II hunting tigers (Hermitage Museum, St. Petersburg), Post-Sassanian $8^{\text {th }}$ century CE plate of a hunting monarch (Sotheby's Antiquities Auction), $5^{\text {th }}-7^{\text {th }}$ centuries CE plate of Hormizd II or Hormizd III hunting lions (Cleveland Museum of Art, 102A Ancient Near East, John L. Severance Fund 1962.150), 5-6 th centuries CE plate of Sassanian monarch hunting

\footnotetext{
${ }^{6}$ It might be argued that the Arabs definitely knew what type of draw the Slavs used because the East Roman/Byzantine armies included these and quite a few of the Slavs were either captured or deserted to the Muslim side. A good example of this is the mass desertion of 30,000 Slavs in 691/2 (Theophanes AM 6184). We would like to reply that this is an interesting point. The Byzantines generally had a low opinion of Slavic archers (see Maurice's Strategikon, Dennis, 1984) and it would be unlikely that Slavic troops recruited into the Byzantine army would be recruited as archers. It is also important to note that the use of ethnonyms in late Roman and Byzantine histories is frequently fairly imprecise. This is particularly noticeable from references to steppe nomads (often called Getae, Scyths and other anachronistic names).
} 
lions with the Parthian shot (Sotheby's Antiquities Auction), 6-7th centuries CE silver-gilt plate depicting Khosrow II engaged in the Parthian shot (Hermitage Museum, St. Petersburg), $5^{\text {th }}$ century CE silver, mercury gilded plate of Bahram Gur hunting (Metropolitan Museum of Art, Accession number: 1994.402, metalwork of Bahram Gur hunting (Hermitage Museum, St. Petersburg, Inv.S-252) (14 cases) or b) both index and small fingers are extended such as in the $4^{\text {th }}$ century CE gilded plate of Shapur II hunting boars (Freer and Sackler Galleries of the Smithsonian Institution, Washington, DC), the late $5^{\text {th }}$ or early $6^{\text {th }}$ century CE plate of a Sassanian king hunting rams (The Metropolitan Museum of Art, New York, Accession number Inv.34.33), the $4^{\text {th }}$ century CE metalwork plate of Shapur II (r. 309-379 CE) hunting lions with the Parthian shot (Hermitage Museum, St. Petersburg, Inv.S-253), the early $7^{\text {th }}$ century CE silver metalwork dish of a Sassanian king hunting ibex and gazelles (Hermitage Museum, St. Petersburg, Inv. S297), the late $3^{\text {rd }}-4^{\text {th }}$ Century CE metalwork dish of a Sassanian King hunting lions (Iran Bastan Museum, Tehran), the late $3^{\text {rd }} 4^{\text {th }}$ Century CE silver-gold metalwork dish depicting monarch or nobleman shooting arrows while riding backwards (late $3^{\text {rd }}-4^{\text {th }}$ Century CE) (Azerbaijan Museum, Tabriz) (6 cases).

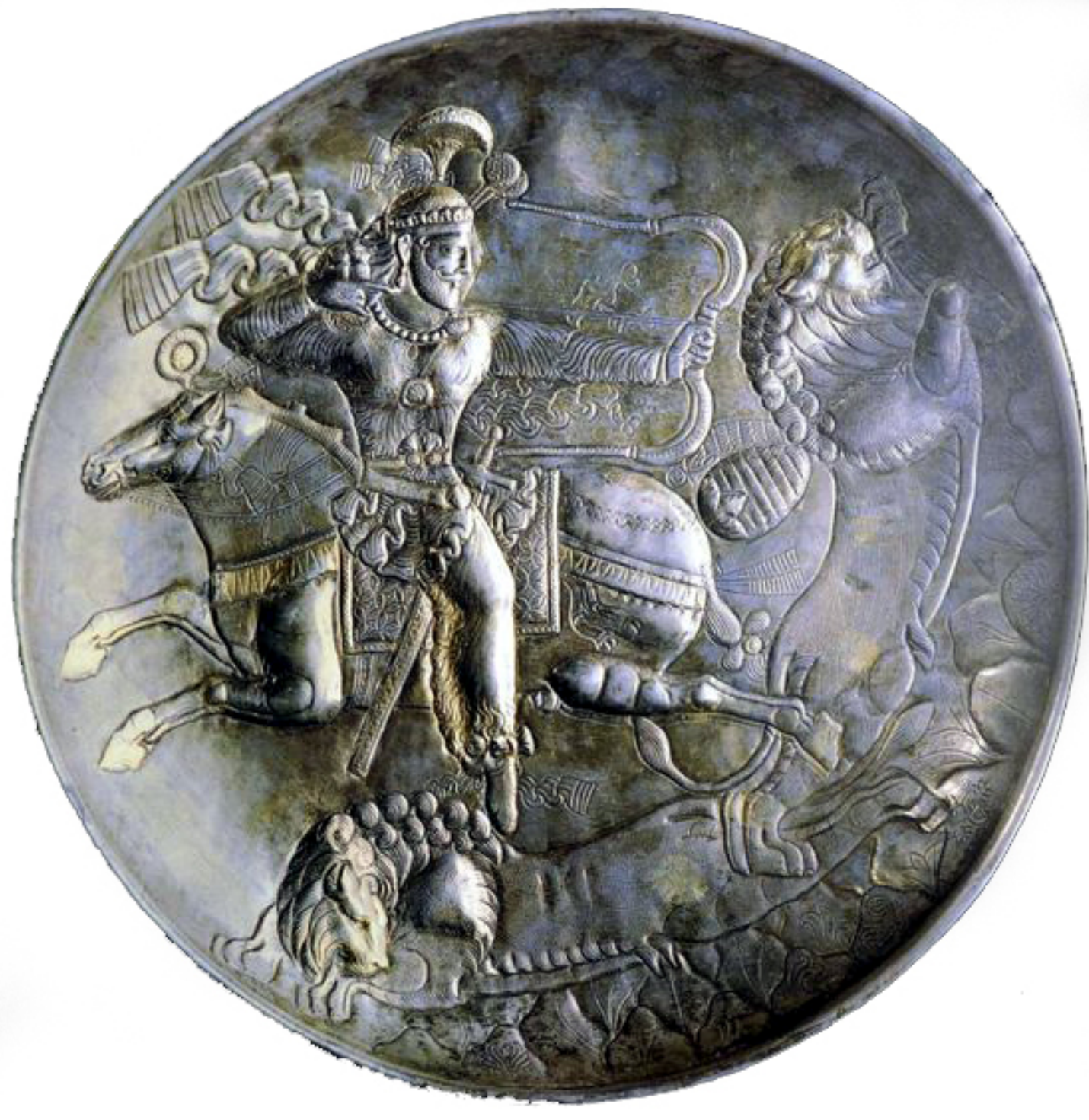

Figure 01: Metalwork dish depicting Sassanian King hunting lions (late $3^{\text {rd }} 4^{\text {th }}$ Century CE), Sari, northern Iran (Iran Bastan Museum, Tehran).

The simplest explanation for the existence of both varieties is that the bent fingers, middle and ring, are drawing the string. Parthian art shows a standard three finger Mediterranean draw (Herrmann, 1977, p. Frontispiece) and the two finger draw is a logical development in the Sassanian era. The Flemish release with the index finger above the arrow and the middle finger 
below is not as balanced for the hand and requires the feathers to be further from the nock for clearance of the fingers on release. This was used by the Cumans (Qipchaqs) and the Hungarians. The Cumans abandoned it after the Mongol invasions. We should note that no archers' rings are recorded in earlier Cuman tombs. The first archer's ring in the Volga area appears after Mongol invasion in the Golden Horde period. The Cumans shown in Hungarian art using two or three finger Mediterranean draw. The position of the little finger in Sassanian draw is rarely discussed, but based on practice rather than speculation, one can provide the following explanation. With the two finger Sassanian draw, the little finger is usually extended and this has a purpose. The extension of the index finger and the little finger increase the speed of the release of the other two. However, with strong bows it is not unusual for the little finger to curl up. This is analogous to the tip of the index finger curling over the thumb, even if it is not tightened. All these different features can be seen on different Sassanian silver plates.

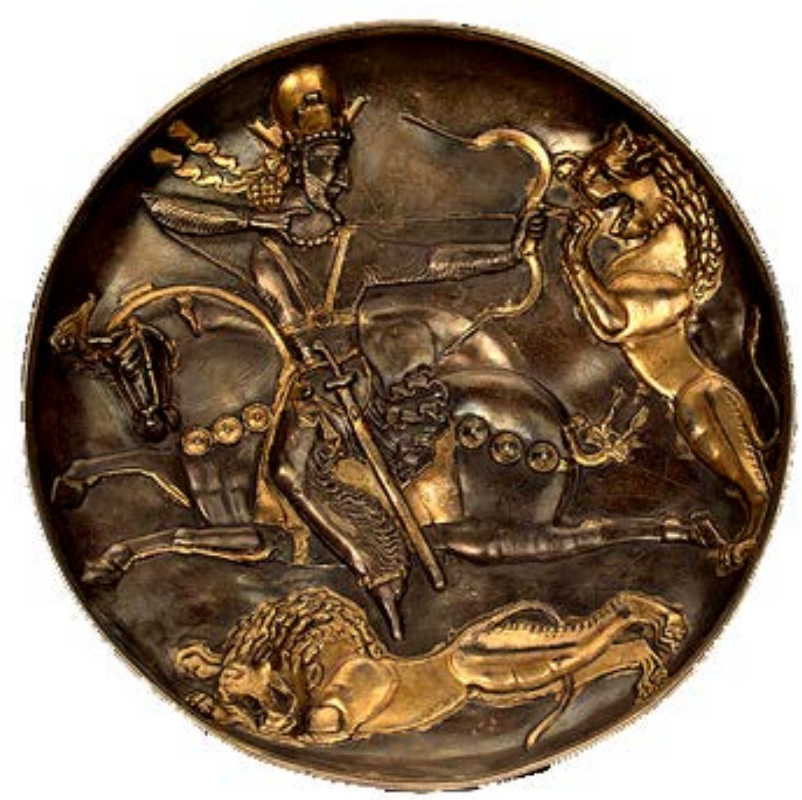

Figure 02: Shapur II (r. 309-379 CE) hunting lions with the Parthian shot (Hermitage Museum, St. Petersburg, Inv.S-253).

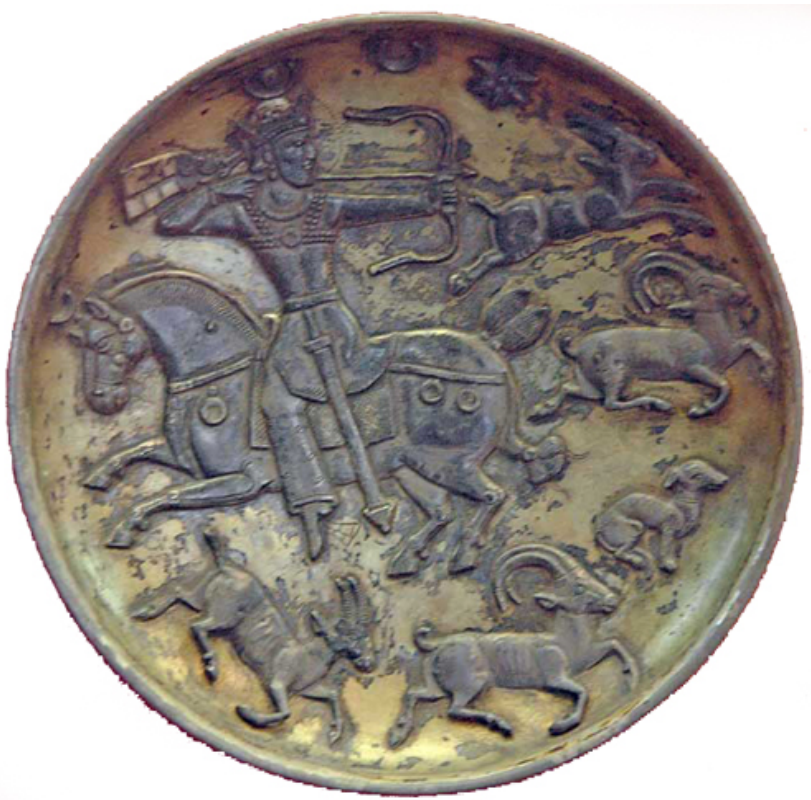

Figure 03: Early $7^{\text {th }}$ c. CE silver metalwork dish of an unidentified Sassanian king hunting ibex and gazelles (Hermitage Museum, St. Petersburg, Inv. S-297).

(d) Further, the Sassanian draw is sometimes compared to Wangju method in Tang China, but thus comparison is untenable.

There are two ways of setting the draw-hand position: placing the ring finger next to the little finger and placing the middle finger over the thumb, with the index finger being placed vertically along the string is the Chinese style. Bending the thumb and hooking the index finger around the end of it is the Mongolian style. (Selby, 2000, pp. 200-201)

One should note that the Wangju method involved putting the forefinger on the string throughout the draw and it was not equivalent to the Sassanian draw. On the other hand, it may be that the thumb ring using Chinese saw Sassanian silver plates and tried to integrate the hand position with their own system. Sassanian silver was popular in China, particularly in the Tang Dynasty after the fall of the Sassanian Empire. The original parts of the book ascribed to Wangju were written in the decades around the year $700 \mathrm{CE}$ after the fall of the Sassanian state. Additions and other editorial changes were made in the Song Dynasty (Selby, 2000, pp. 210-211).

(e) Successful military establishments rarely abandon tried and true methods. When the Manchu conquered China they forced the Chinese to adopt their bows and thumb ring styles (as well as haircuts and clothing) (Elliott, 2001, pp. 400, n. 104). Within a century of the Arab conquest, the thumb draw was universal. At least the eastern half of the Sassanian Empire must have already been using the thumb draw by then. If the western half was still using the older style, the 
technique may have been eliminated with the western armies. The Asāwera may have been Khorasanian rather than the western troops of the King (Bosworth, 1987). ${ }^{7}$

(f) There are silver finger tips which are thought to be used for protecting the finger tips for finger draw (Overlaet, 1998, pp. 290-297). These silver finger tips are well known and the archaeologist speculated that they were connected to archery, but in reality they are neither suited to the Sassanian draw nor to the invented purpose of protecting the index finger. If they use the two middle fingers over the thumb draw, they must have the bowstring obliquely across the face of the thumb so that the hand is turned out. This is used as an argument for the silver plates showing a thumb draw. However, in this position there is no chance of the index finger being struck or abraded by the string. This is likewise true for the other protectors like the leather ones. We do not know what these silver tips were for. They could have been votive objects, they may have been for playing the lute or the harp.

(g) There is also an analysis of the Sassanian harness on the archer's drawing hand based on Adam Swoboda's initial hypothesis on the Sassanian draw. He changed his explanation in the next edition by adding an extra method (Swoboda, 2015, pp. 102-104). We should know that hanging thumb rings from the waist with a string was practiced by the Mogul Indians so that they could show off their jeweled thumb rings. The loop was attached to the belt not the ring. The last thing an archer needs is an extra piece of gear on their hand or between their thumb and the inside of the back of the ring (Koreans used something wrapped around the back of the ring to tighten the fit in their rings). Very early Chinese rings had a hole in the thickness of the back of the ring to take a thin silk loop. While in the earliest ring ( $\mathrm{Fu} \mathrm{Hao}$ ) this was thought to be for holding the ring on the wrist (Chang, 1986, p. 232. Fig. 47, 4), this was the conclusion of an archaeologist not a practicing archer. Later rings the hole was so small that it would admit a single silk thread. There is a later gold ring from China that has been reconstructed with a wrist cord based on the large hole. This is more a case of earlier archaeological writers influencing later ones than real proof.

(h) Comparisons are also made to the Nubian thumb rings where they were used as rings on the thumbs (Emory, 1967, pp. 78 \& 83). But one should note that there is no evidence of them being used in archery although they were suitable to do so. Their identification as archer's rings is based on their visual similarity to Manchu thumb rings used 1500 years later in China. Their use is attested to a period between the $2^{\text {nd }}$ and $4^{\text {th }}$ centuries so they were not contemporary with the Sassanian occupation of Egypt. How far the Sassanians moved up the Nile valley is not documented so it is not possible to make any assertions that the Sassanians were generally aware of the thumb draw in early periods. Even if they were the question remains why would the conquering Sassanians adopt the supposed archery style of the Nubians (i.e. the extinct Blemmyes and the Nobades). These two tribes are associated with the so-called X-Group culture, in whose tombs thumb rings were found (Emory, 1967, pp. $78 \& 83$ ).

(i) Another important point is that the Sassanian Empire lasted more than 400 years. One can assume that until the Hephthalite invasions and the subsequent alliance with the Turkish Empire they had no reason to change their traditional archery practices. They were militarily

\footnotetext{
${ }^{7}$ Bosworth (1987). It might be argued that we seem to be aware of the fact that the various different nomadic peoples used different archery techniques and somehow still managed to hold their own against other nomadic tribes that used different techniques, but we fail to analyze the reasons for this. It might be argued too that we should also explain more clearly the significance of the different types of equipment for the effectiveness archery. We need to emphasize that the purpose of the article is not to document the movement of the use of the thumb draw technique. However, a look at the historical record shows that at the time of the Sassanian Empire the western Eurasian steppe was almost entirely using finger draws. At the end of the sixteenth century only the Hungarians were still using finger draws. In the wake of the Mongol conquests, the thumb draw was universally adopted by all the major steppe powers. This may be only fashion, following the most successful conquerors. In the Middle East the thumb draw was adopted earlier (the earliest dated thumb ring was found at Fustat in Egypt from a seventh-eighth century context) probably as a result of the penetration of Oghuz Turks. When Qipchaq Turks where inducted into the Mamluk corps, they were taught the use of the thumb ring, not their native two finger draw (called in England the Flemish release and different from the Sassanian style).
} 
successful and most of their defeats were in times of internal conflict or attacks from both east and west. With the Hephthalite invasion, major parts of the Empire were either occupied or devastated. It was during a major effort to reform the army under Khosrow I that might have been when it was thought to change some basic aspects of military practice. However, this is partly based on the similar organization in the Byzantine Empire. Maurice's Strategicon of about 600 mentions that an archer should be able to shoot "either in the Roman manner or the Persian manner", which the translator (Dennis, 1984, p. 11 note 2) on the authority of Bivar (1972, p. 285) associates with the steppe nomad tradition (thumb draw) and the Sassanian (three fingers under). There is a large and undocumented problem with this. Until the Oghuz migrations, all the steppe nomads the Byzantines came in contact with used a two finger Flemish release. The possible exception is the Avars. Coulston (1985, p. 277) mentions a bone thumb ring in The Art of the Avars (Erdelyi, 1966, p. 44) ${ }^{8}$. The Cumans were still using it at the time of the Mongol invasions and the Hungarians were using three fingers, even later in the $15^{\text {th }}$ century according to an eye witness (de la Broquière, 1988, p. 163). The Turkish Empire (the Gök Türks), with whom the Byzantines allied against the Sassanians and with whom the Sassanians allied against the Hephthalites ${ }^{9}$, used the thumb ring so there is a mechanism whereby both could have adopted the thumb ring in the sixth century. Note that the Byzantines did not exclusively adopt the thumb draw and it is likely neither did the Sassanians if this scenario happened in reality. We can thus safely assume that the Sassanians used both two finger draw and thumb draw by the end of the empire. Maurice only uses the names Persian and Roman without describing the differences. Bivar assumes it is between thumb draw (Roman) and fingers (Persian), which is a good guess, but only that. The advantage that the thumb draw gives is not apparent to modern archers because they draw to the chin or the side of the mouth so changing to a thumb draw only affects the arrow's performance by the reduction of friction between three fingers on the string and only the thumb. However, if one observes the draws shown in old illustrations (especially the plates) they are designed to bring the elbows and shoulders into alignment to give the strongest possible draw. This is specifically stated in most mediaeval archery manuals in the Middle East. In this scenario, the extra draw length (about a palm's width) obtained by using the thumb draw is significant. Procopius describes the difference between Persian and Roman bows based on his analysis of the areas that each army concentrated on. If you intend to shoot large numbers of arrows, it makes sense to use bows that can be shot more often without tiring the archers unduly. The Romans were possibly interested in penetrating armor while the Persians may have been concentrating on rate of shooting. It should be noted that a stiffer bow does not assure a faster more effective arrow. The combination of bow design, arrow weight and the archer's skill determine effectiveness. ${ }^{10}$

\footnotetext{
8 This device was not a thumb ring but a pointed bone implement for untying knots and the archeologist finding it used the term "stringing" to indicate attaching and detaching the string rather than drawing and releasing it. This kind of imprecision was also associated with translations of such famous archeologists as Rene Grousset.
}

${ }^{9}$ See Sinor (1990, pp. 298-301), for a discussion of the complicated relationships between steppe powers, the Byzantine Empire and the Sassanian Empire.

10 It might be argued that we fail to state clearly why it is important to separate the different kinds of finger and thumb draws from each other. One might think that this failure has probably resulted from the common faulty a priori popular assumption that the thumb draw would equate more a powerful bowshot, which in one opinion is not the case. It could be suggested that much more important were the physical aspects of the archer - in particular his physical strength and length of arms - together with the performance characteristics of the bow and arrows, which were once again customized for each user. We would like to stress that this speculation contains several unsubstantiated assertions. Firstly, the various forms of finger and thumb draws appear to be cultural indicators of the transfer of archery technology and techniques. One could make the mistake of conflating powerful and bowshot together as if that were a simple equation. As archers know, range and hitting power are different things. A bowshot can be long and weak, short and powerful, long and powerful and short and weak. What might be meant is what contributes to an effective shot. Such an opinion shows a modern sport archery bias that has little place in a military context. Two statements are repeated in the context of bows and their users in military and archery manuals. One is that the bows should be in proportion to the strength of their users. The other is that all users should have bows that are less than the maximum strength that they could draw. Bows were not "again customized for each 
In the following we will describe different platforms used to practice archery be it hunting or warfare. We classify them into foot archery and mounted archery. The latter is sub classified into: horse archery, dromedary archery and elephant archery._The system of the classification of the metalworks is based on the paradigms of Akhavan-Aghdam (2014) as well as Yasinzade, MoussaviKoohpar and Afhami (2013). We should note that whether the ground, the back of a horse, an elephant or a camel is used, it is critical to how and why archery is practiced. The technical method of drawing the bowstring will stay the same, but the type of archery varies. On foot the archer is usually shooting at a distance. He depends on spearmen and shields to defend him if his target approaches too close. He can concentrate on individual targets and rapid shooting. The horseman can rapidly approach and retreat. His skills are concentrated in shooting while in motion. His tactical considerations will affect his methods of aiming and how quickly he would need to shoot. The elephant and camel archers are nearly always shooting down at their targets. Their speed of maneuver is less than the horseman's but more than the infantry who are usually confined by the mass of their companions. ${ }^{11}$

\subsection{Foot archery}

There is one existing depiction of Sassanian foot archery at the Hermitage (Inv.S-216), namely the figure of Pirouz shooting missiles at rams during the hunt. Pirouz's primary weapon in this plate is his bow and except for a partially visible scabbard slide sword suspended at Pirouz's left side, the monarch is not seen with any other weapons. As Pirouz draws his bow, he aims his shot at the prey with his left hand's index finger on the bow grip pointing in the direction of the arrow, a technique consistent with Sassanian archery. Another consistent feature of a Sassanian draw is the extension of the index finger of the right hand pulling the bowstring. It seems to be two

user" as some suggest except in the matter of bow strength as mentioned. One of the authors is a flight shooter and two are archers of some experience, and we would like to emphasize that the length of the archer's arms has little or no effect on the effectiveness of their archery techniques. We stress again that there would be standard military arrows rather than dozens of customized classes, an archer can increase their draw length by drawing back as far as the right shoulder (for a right handed archer) or decrease it by drawing it to the corner of the mouth. In the continuum between these two points, there are multiple anchor points. In the real world of standard military arrows, archers of different heights (which can correlate roughly to arm lengths), the archer would adjust the draw length to where the arrow point came back to the hand with a corresponding point on the face, like the lips, where a consistent height for the rear of the arrow could be maintained. On these grounds, what advantage would a thumb draw have over finger draws? The obvious one is that is much easier to draw past the ear with the thumb draw than with the fingers because the string comes off the thumb away from the archer's body whereas it comes off the fingers towards the archers' body increasing the risk of injury to the archer and deflection to the arrow. All Sasanian depictions of archers show a draw behind the head. The two finger draw has less deflection than the standard three finger draw and this can be demonstrated by practicing both draws as has been shown by two of the authors. In order to cover the technical aspects of this particular objection, the article would have to be book length.

${ }^{11}$ In general, one should be very careful and aware of the distinction between primary sources and secondary and tertiary ones. For instance, Procopius does not refer to the Sassanian use of elephants. All the subsequent discussion of their use is based on secondary sources and later deductions and extrapolations. Most of these interpretations liberally borrow from other authors who were not contemporary or who were not writing about elephants in a Sasanian context. Our article is usually more restrained and less fanciful. Regarding elephants, it cannot be doubted that elephants were sometimes used in Sassanian armies. Whether they were mobile command or observation post, tactical rallying points, transport or tactical fighters is hard to determine from contemporary sources. The plates show them in hunting situations. Taq-e Bustan also shows their use in another hunting context. Allsen (2006) makes a point of the importance of the prestige of the royal hunt. Elephants are clearly a prestige animal. The fact that you can afford their upkeep proves your wealth and power. However, from the time of the late Roman Republic they have been considered more of a threat to their own army when they stampede rather than of a great tactical significance. It is possible on the north eastern frontier against Turkish armies that had never seen them before they may have had an initial impact, but a horse archer could easily pick off the mahout and anyone on their backs without getting close enough for his horse to panic. In later periods, the wonderful array of weapons the Indians developed for the elephants in their armies probably had more visual effect that real mayhem. This is not to say there were not tactical uses for elephants, but it is how to see how effective they would have been against a Roman or Byzantine army who had centuries of tactical doctrine on how to deal with elephants. 
varieties: a) the index finger extended and b) both the index finger and the small finger are extended. The Sassanian foot archer was deployed in both set-piece battles and siege warfare (Ammianus, 1996, XIX, V, 1; XXIII, VI, 83; XXIV, VI, 18), being tasked with bombarding the enemy with massive barrages of missiles (Zakeri, 1995, p. 51) with a buckler suspended on his shoulder for protecting his head and neck during battles (Inostransev, 1926, p.25, Footnote 3). Sassanian archers often positioned large palisade type shields (Jandora, 2010, p. 107) to their front when firing highly effective arrows against enemy formations from a static position (Hekmat, 1964, p. 1088). Pirouz, shown on a Sassanian silver plate from the Hermitage Museum does not carry a buckler and has no shield (palisades or otherwise) in front of him, most likely due to the hunting context of his depiction. ${ }^{12}$

The Pirouz plate also highlights the importance of foot archery to the Sassanian Spah that regarded infantry archers as a highly valued military asset. The Spah also fielded an elite unit of archers led by a Tir-bad commander entrusted with the defense of the royal throne and the Drafsh-e Kaviani imperial standard. The primary role of the foot archers was to unleash a powerful and voluminous missile barrage into enemy formations with the intent of weakening these for the follow-up lance attacks of the Savaran armored cavalry. The composite bow, such as the one held by Pirouz in the Hermitage plate (Inv.S-216) allowed for the application of the Spah's doctrine of shooting missiles towards the enemy from a safe distance. Foot archers were also responsible for the suppression of the enemy's own archery corps as well as infantry and cavalry counterattacks. If enemy troops, notably Romano-Byzantine infantry, managed to reach the Sassanian front lines, the foot archers would most likely have been capable of firing backwards in the "Parthian shot" style if forced to retreat. In siege warfare, foot archers' archery barrages could also be a psychological weapon intended to demoralize the besieged enemy. ${ }^{13}$

Possibly the best combat arm of their type in the Classical era, Sassanian infantry archers were highly respected by the Romans as attested to by Procopius (1914, I, p. 18) and Ammianus Marcellinus (1996, XXV, I, p. 13). The Spah especially valued ambidextrous archers given their ability at (a) holding the bow grip with their left hand and pulling the bowstring with the right hand as well as the ability to (b) hold the bow with the right hand while pulling the bowstring with the left hand (Inostransev, 1926, p. 25). It means that the Spah valued archers who could shoot equally well from the left or right as this could protect against surprise flank attacks (Inostrancev, 1926, pp. 13,$25 ; 1969$, pp. 42-43). We would like to point out that ambidexterity is only a real advantage for horseback archers, since infantry archers only need to turn around to shoot to the right, whereas a horse limits the rightward turning of his rider. Since horse archers were usually moving, turning the horse to accomplish a right hand shot would also change direction which is tactically significant. The Pirouz plate shows the monarch holding his bow with his left hand as his right hand pulls the bowstring: this presents Pirouz as a right-handed archer. The depiction of a monarch (Pirouz) as a foot archer is would suggest the high status of this type of warfare for securing battlefield success. An example of this occurred at Anglon, Armenia in 542 CE where a force of 30,000 RomanoByzantine forces faced smaller Sassanian force of 4000 troops led by Sardar (commander) Nabed

\footnotetext{
12 It might be argued that the use of massed volleys in the context of battles has nothing to do with the hunting archery as depicted in the plates. However, this is a basic misunderstanding of the skills involved in archery. The ability to shoot on cue, to shoot at an individual target, and to shoot at a group of people at a distance are not disconnected features of archery. To teach a group of archers to shoot on command is the matter of half an hour even if that. This is not shooting in the manner of a historical movie where everyone draws their bow, holds interminably at full draw and then releases on command. That is an anachronistic reference to the totally different requirements of a musket drill. There the weapon can be held indefinitely cocked, but the rate of shooting is so slow that everything was done to maximize the effect of a volley. With archers one only needs to say "Shoot!" The high rate of shooting compared to muzzle loaders meant that a continuous stream of arrows was produced. One other command would be needed which is "Stop!" since arrows would otherwise be exhausted. This refers to infantry archers. Horse archers probably would start shooting when in range and stop when out of effective range. The maneuvers that brought them into range would be the effective command.

13 Note that we do not say infantry used the Parthian shot in retreat, but they could have. The possibility is suggested by the fact that most modern archers can do it. Its advantages would be determined by circumstances. It would be certainly more useful than walking backwards.
} 
(Nabades) (Greatrex \& Lieu, 2002, p. 116). Despite outnumbering Nabed's forces by almost 8-1 they suffered a decisive defeat due to the effectiveness of Sassanian foot archery. Nabed allowed the Romano-Byzantines to advance into an ambush (Stein, 1949, p. 500), with Procopius describing the subsequent battle:

...all of a sudden the men who were in ambush [Sassanian Spah]... came out from the cabins along the narrow alleys... great confusion fell upon the Roman army, and Nabedes let out the whole Persian force upon his opponents. And the Persians, shooting into great masses of the enemy in the narrow alleys, killed a large number without difficulty... Romans did not withstand the enemy and all of them fled as fast as they could... especially all the generals... kept fleeing still faster... had not the courage to array themselves against the Persians if they overtook them... this proved a disaster for the Romans... so great as to exceed anything that had ever befallen them previously... great numbers of them perished and still more fell into the hands of the enemy... (Procopius, 1914, XXV, pp. 1-35).

The Sassanian victory at the battle of Anglon was achieved solely through foot archery without the participation of the Savaran armored lancers who were the main battle striking arm of the Spah.

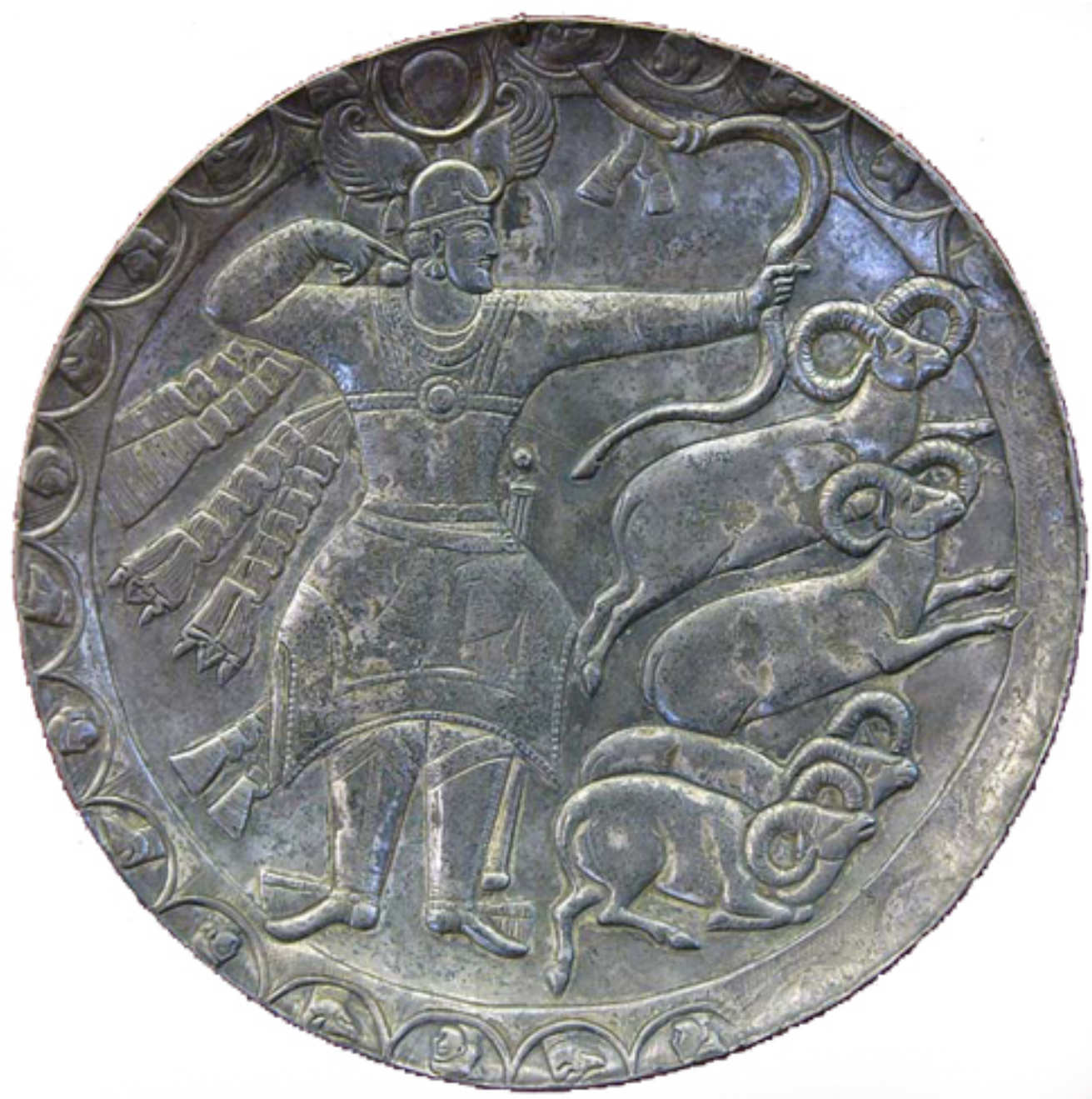

Figure 04: Plate depicting King Pirouz (r. 459-484 CE) in a hunting area, discovered in the town of Tcherdyne in the Perm region (item dated to 460-480 CE) (Hermitage, Inv.S-216).

\subsection{Horse Archery}

Horse archery was a vital military asset for the Spah from the earliest days of the Sassanian Empire. Roman Emperor Alexander Severus' (r. 222-235 CE) defeat at the hands of Ardashir I (r. 224-242 CE) at the Battle of Ctesiphon (233 CE) is attributed by Herodian to the skillful archery of the Savaran: 
...The Persian king [Ardashir] attacked the [Roman] army with his entire force catching them by surprise and surrounding them in a trap. Under fire from all sides, the Roman soldiers were destroyed... in the end they were all driven into a mass... bombarded from every direction... the Persians trapped the Romans like a fish in a net; firing their arrows from all sides at the encircled soldiers, the Persians massacred the whole army ...they were all destroyed... this terrible disaster, which no one cares to recall, was a set-back for the Romans, since a vast army... had been destroyed. (Herodian, 1970, VI, 5, pp. 5-10)

Herodian emphasizes the high level of horse archery training by the Savaran whom he describes as being proficient in the "...use the bow and the horse in war...reared with these from childhood...never lay aside their quivers or dismount from their horses..." (Herodian, 1970, VI, 5, pp. 1-6). The training manuals of the Ayin-nameh have provided a comprehensive description of kinesthetic details critical to the effective discharge and delivery of arrows with respect to body posture, eye motion, positioning of the hands' fingers, etc. (Inostransev, 1926, p. 35). Seasoned Sassanian warriors would continue their intensive training during peacetime, in a training regimen broadly classified as Tir-Wazig (arrow play) (Tafazzoli, 1993, p. 193). The seminal role of horse archery in the Spah's battle doctrine may explain in part as to why a large proportion of excavated Sassanian metalworks often display this martial form. These can be broadly categorized into four categories of horse archery: frontal shot, Parthian shot, shooting with stirrups and shooting while riding the horse backwards. However, this classification can be problematic because the only plates depicting shooting while using stirrups are post-Sassanian plates. We infer that at the end of the Sassanian period, stirrups appeared in Eastern Iran, either as a Hephthalite or Turkic introduction. The actual difference in having stirrups on the saddle is more apparent in riding than shooting. One should note that the saddle itself gives the required stability for the various shots. Standing in the stirrups to shoot was an advantage, but early stirrup leathers were so long that it was only a minor improvement. Later, in the time of the Oghuz and Seljuk invasions, shorter leathers were enabling the archer to elevate himself more above the saddle increasing his flexibility and independence from the horse's gait, but their primary advantage was to make longer distances less troublesome to the horse and the rider. In reality the plates show a subset of horse archery techniques limited by the ease of depiction in metal and the requirement to show the king in a powerful and graceful posture. Shooting at right angles to the horse's direction of travel, shooting down at a slant or up in the air were probably eliminated because they make the king look awkward. The categories of dromedary (camel) and elephant archery are discussed in a separate section in this paper.

\section{(1) Frontal horse archery}

The first category of mounted archery, shooting forward, is displayed in ten known Sassanian metalwork plates housed in the Freer and Sackler Galleries of the Smithsonian Institution, Washington, D.C., Hermitage Museum in St. Petersburg, Arthur M. Sackler Gallery Exhibit in Wahsington, D.C., The Metropolitan Museum of Art in New York, the Arthur M. Sackler Gallery Exhibit in Washington, D.C., Bibliotheque Nationale in Paris, with another having been displayed in a Sotheby's Antiquities Auction and one recently discovered plate also reported in Sasanika.org. In all of these plates a regal figure is displayed with his bow drawn while aiming at game during the hunt. All of these plates display a Tir-dan (quiver) suspended to the right side of the hunter-king. Five of these (Shapur II hunting boars, Freer and Sackler Galleries of the Smithsonian; Shapur III hunting boar, Hermitage Museum; Sassanian king hunting rams, Metropolitan Museum of Art; Sassanian king hunting deer and various prey, LACMA; Yazdgerd III hunting, Bibliotheque Nationale; Khosrow II hunting tigers, Hermitage Museum) also display a partially visible sword hilt slung to the left of the rider.

None of the plates depicting mounted forward-shooting archery (Shapur II ,Freer and Sackler Galleries of the Smithsonian; Shapur III, Hermitage Museum; king hunting rams, Arthur M. Sackler Gallery Exhibit; king hunting rams, Metropolitan Museum of Art; king on ostrich hunt, Sasanika.org; king hunting deer and various prey, LACMA; king hunting gazelles, Arthur M. Sackler Gallery Exhibit; Yazdgerd III hunting, Bibliotheque Nationale; Khosrow II hunting tigers, Hermitage Museum; post-Sassanian depiction of a hunting king, Sotheby's) display any other weapons. 


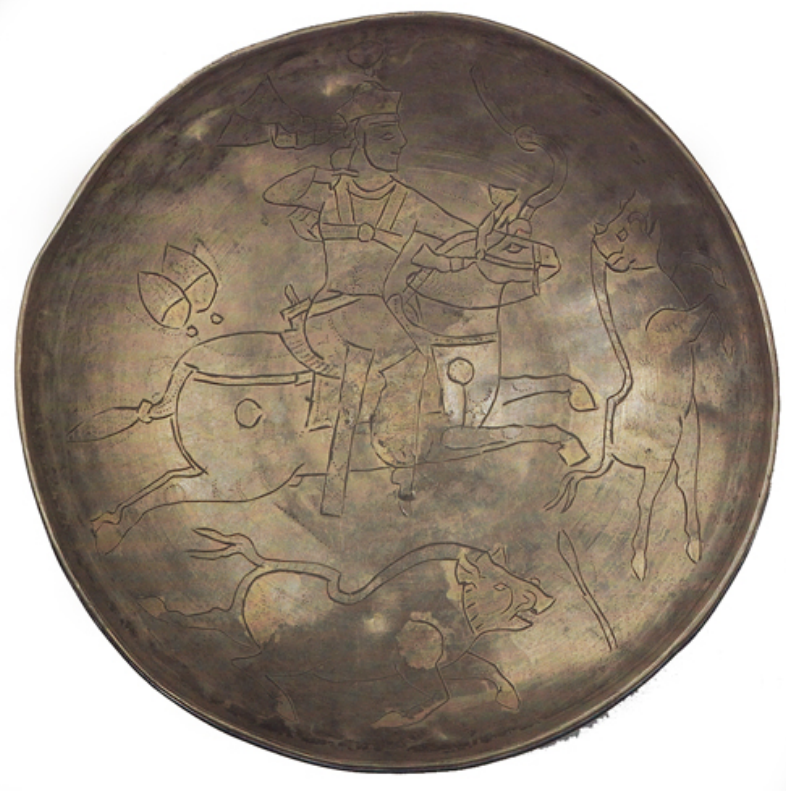

Figure 05: Sassanian silverwork plate depicting Shapur III hunting boar (Hermitage Museum, St. Petersburg)

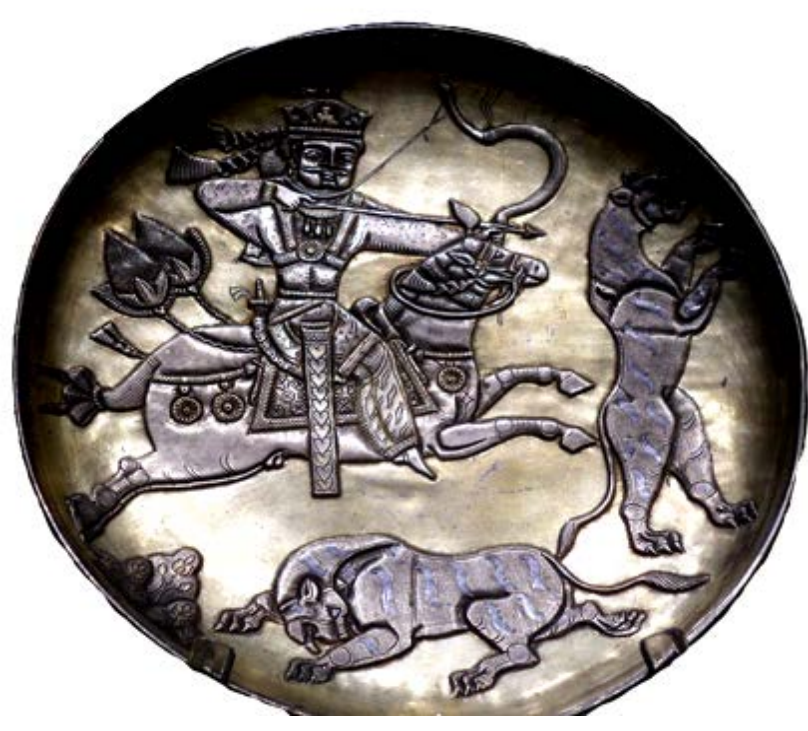

Figure 06: Early $7^{\text {th }}$ century CE Sassanian gilt silver dish of Khosrow II hunting tigers (Hermitage Museum, St. Petersburg)

\section{(2) Horse archery with the Parthian shot}

The Parthian shot involves the shooting of arrows backwards while riding away from prey or enemy combatants. There are six Sassanian and post-Sassanian metalwork plates currently known depicting horse archery with the Parthian shot. These are currently housed in the Cleveland Museum of Art, the Hermitage Museum in St. Petersburg with another having been displayed in a Sotheby's Antiquities Auction (Hormizd II or Hormizd III Hunting Lions, Cleveland Museum of Art; Shapur II hunting lions, Hermitage Museum; Sassanian king hunting ibex and gazelles, Hermitage Museum; Sassanian monarch hunting lions; Sotheby's; Khosrow II hunting, Hermitage Museum; Pur-e Vahman engaged against pursuing lion (Hermitage Museum). All of these plates depict the king engaged in the Parthian shot, with clear displays of the Sassanian bow, archery style, and equestrian attire. All of the (regal) figures in the plates are fully depicted with a scabbard slide sword. This is because while the sword is suspended on the rider's left side in the Partho-Sassanian fashion, this weapon is now fully visible (entire hilt and scabbard) on the figure's fully exposed left side as he turns backwards to engage in the Parthian shot. The Parthian shot as a combat technique was deployed into the last days of the dynasty. This is attested in the early post-Sassanian (late $7^{\text {th }}$ or early $8^{\text {th }}$ century CE) metalwork plate) of Pur-e Vahman engaged in the Parthian shot (Hermitage Museum, St. Petersburg, Inv.S-247).

The depiction of the Parthian shot in Sassanian and post-Sassanian metalworks would suggest that this tactic was a standard element in the Sassanian battle order. This tradition was inherited from the Parthian Spada. Plutarch's description of the Battle of Carrhae for example describes an episode of Roman cavalrymen pursuing Parthian horse archers who then unexpectedly turn backwards in their saddles to fire with the Parthian shot against their pursuers. The feigned retreat combined with the Parthian shot was integral to Sassanian battle tactics from the early days of the dynasty. The feigned retreat-Parthian shot was critical especially in battle scenarios where a Sassanian army had suffered defeat or being forced to withdraw. The feigned retreat-Parthian shot strategy could also be an effective strategy even if no actual defeat was imminent. The enemy could be lured into pursuit who would then be subjected to the Parthian shot. Sassanian capabilities of turning a rout into a victory was respected by the Romano-Byzantines. Procopius for example notes that following his victory over Sassanian forces in the Battle of Dara (530 CE), general Belisarius restrained his troops from pursuing their defeated foes. As noted by Procopius in the $6^{\text {th }}$ century CE: 
... the pursuit was not continued by the Romans over a great distance. For Belisarius and Hermogenes refused absolutely to let them go farther, fearing lest the Persians through some necessity should turn about and rout them while pursuing recklessly. (Procopius, 1914, I, p. 14)

Procopius has noted of the dangers of pursuing Sassanian cavalrymen in flight given their abilities to suddenly strike their pursuers with the Parthian shot. The pursuers who would be rushing forward, would be badly mauled by the discharged arrows of the "fleeing" Sassanian cavalrymen ${ }^{14}$. The dislocation caused by the Parthian shot could result in a loss of cohesion among the pursuers, allowing the "fleeing" Savaran to wheel about to then launch more archery attacks against their pursuers. This could entail attacks against the pursuers' flanks, front or rear, which could even result in encirclement as happened in the aforementioned Battle of Ctesiphon in 233 CE. If the counterattack resulted in further dislocation of the pursuing troops, the Savaran then could choose to deploy their close quarter combat weapons such as swords, axes, or maces or instead opt to launch lance attacks (Matofi, 1999, p. 152). In contrast to Procopius, the Strategikon attributed to Emperor Maurice (r. 582-602 CE) states that Sassanian cavalry were incapable of turning against their pursuers when retreating (Dennis, 1984, XI, I). It might be argued why the Stretegikon and Procopius provide contradictory descriptions with respect to the Savarans' ability to turn against their attackers when pursued, given that the Parthian shot was clearly a valued military asset to the Sassanian dynasty's final years. The obvious answer is the military reforms of Khosrow I, who introduced a more centralized and perhaps less flexible system. Much of what is written here about the Sasanian military use of the Parthian shot could be said on any horse archer army. However, the fact that flexibility seems to have been reduced in the latter part of the dynasty could be a reaction to fighting against enemies who would not be drawn into intemperate pursuit.

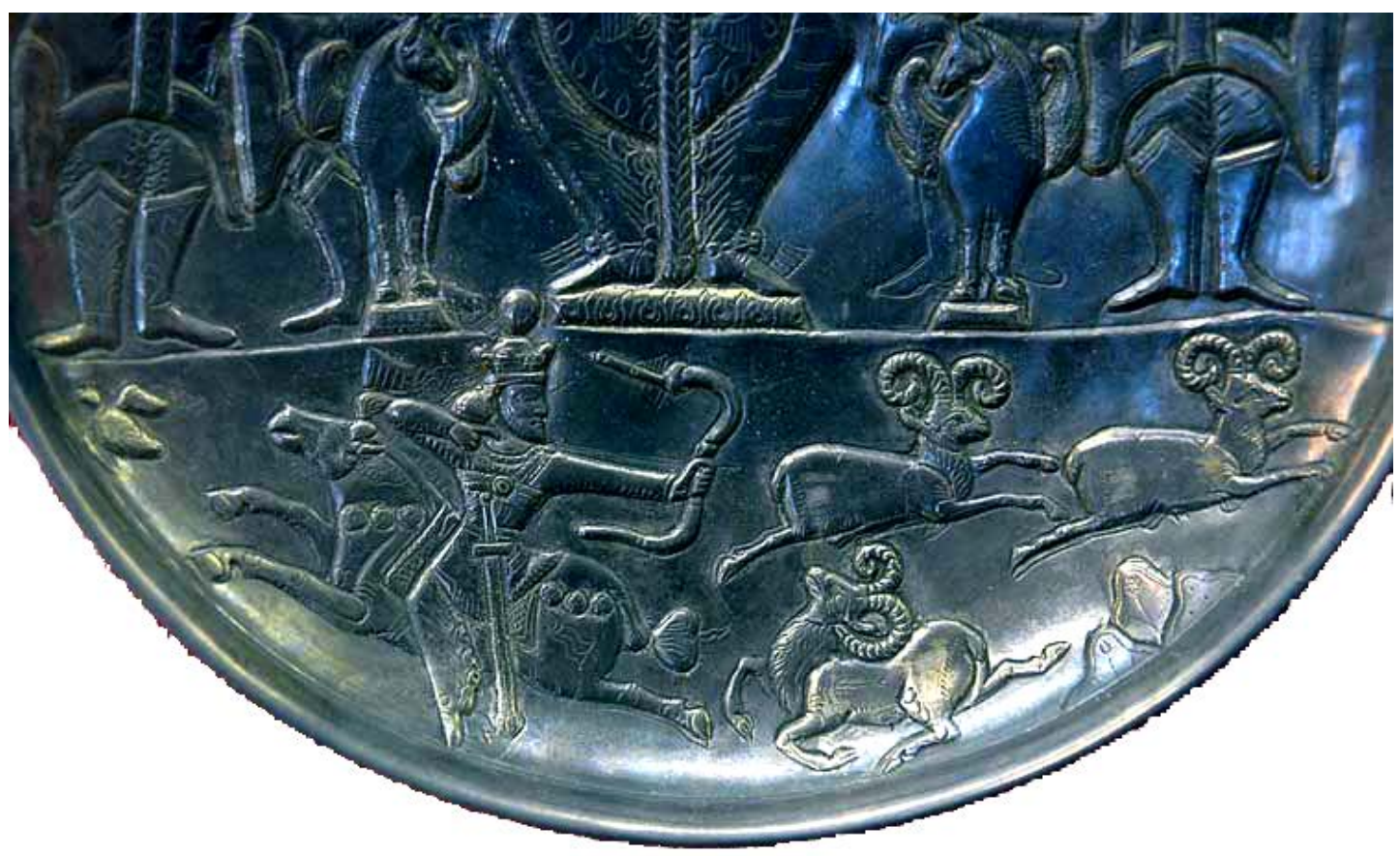

Figure 07: Close-up detail of silver-gilt plate of 6-7th centuries CE depicting Khosrow II engaged in the Parthian shot; discovered in Perm Region, Russia (Hermitage Museum, St. Petersburg).

\section{(3) Horse archery with Stirrups: the case of Pur-e Vahman}

One of the horse archery plates displays riders riding horses with possible stirrups (the post-Sassanian $8^{\text {th }}$ century CE silver-gilt metalwork plate depicting a hunting monarch with his feet in "stirrup-posture" Sotheby's; with another one with a definite display of stirrups (a post-

\footnotetext{
${ }^{14}$ Maurice's Strategikon (Dennis, 1984) specifically mentions the dangers of attacking pursuing Persians. It also compares the dangers of attacking fleeing nomads (Turks, Avars etc.) who would often lead the Romans into an ambush.
} 
Sassanian silver plate attributed to the $7^{\text {th }}$ or early $8^{\text {th }}$ century, Hermitage Museum, St. Petersburg, Inv.S-247). Before addressing this discussion is the issue the debate of whether the Sassanians actually utilized stirrups. Karantabias asserts that the Sassanians did not utilize stirrups based on his observation that "at Taq-e Bostan... Khosrow II is portrayed in his heavy armor, yet the stirrup is absent... leads us to assume that... Sassanid army must not have stirrups..." (Karantabias, 2005, p. 30). This assertion however is based on the assumption that the feet of the Taq-e Bostan rider (Khosrow II) do not rest on stirrups. In practice the rider's feet are not visible, as these have broken off over time. In addition, it is not possible how the rider holds the reins as his small shield on his left forearm serve to hide the reins he would presumably be holding. The rider's right hand holds aloft a spear or lance; this is partially visible given that parts of it have broken off, leaving only part of the shaft visible. Michalak (1987, p. 82) notes that despite the partial damage to the feet of the knight at Taq-e Bostan, "...the firm settling in saddle and the position of the legs, which are moved slightly forward and not hanging loosely down...". This leads him to suggest that the Taq-e Bostan cavalryman probably used stirrups. This is concurred by Herrmann who notes that the lack of support at the back of the Taq-e Bostan rider's saddle would suggest that stirrups must have been used to ensure that rider's stability. We would like to stress that this argument is flawed since in oriental saddles, the cantle is usually covered by the rider's clothes. Early Sasanian rock carvings clearly show this where coats and tunics are covering the rear horns of the four-horned saddles used in this period.

Herrmann also notes that the hunting scene panels along the ingress into the vault of the cavalryman (Khosrow II), show riders' feet positioned in a way that can only be consistent with the use of stirrups ${ }^{15}$. Put simply, the figures in the hunting scene at Taq-e Bostan do not display the "ballerina" foot posture seen in earlier Sassanian rock reliefs such as Naqshe Rostam as well as the metalwork plates discussed in this paper. This is a valid observation. However, it should be noted that in Achaemanian reliefs from Anatolia, the foot position is much closer to the horizontal heel position than the ballerina "toes pointed downwards position". This might mean that an alternate foot position is being shown. Greek depictions often have a more horizontal foot and modern bareback riders also adopt this position. The point of this comment is that neither depiction is a guarantee of the use or absence of stirrups.

Nicolle has reported of one Sunni Hadith citing the Prophet Muhammad's observations of the Persian usage of the stirrup (Nicolle, 2005, p. 21). The significance of this Sunni Hadith pertains to its chronology, as it would roughly correspond with the protracted war between the Sassanian and Byzantine Empires in 603-628 CE. Finally, Karantabias' hypothesis that "Persian conservatism" (Karantabias, 2005, p. 30) prevented the Sassanians from adopting stirrup technology from the nomads of Eurasia and Central Asian is contradicted by the find of iron stirrups dated to the late $6^{\text {th }}$-early $7^{\text {th }}$ centuries CE in Iran's Marlik region (Römisches Germanisches Museum, Mainz, Germany, Inv. 037985 and Inv. 037986). The finds at Marlik would suggest that the Sassanians had already adopted stirrups at the time of Khosrow II or possibly earlier. ${ }^{16}$ Deployment of the iron stirrup greatly enhanced rider stability, enabling him to deliver more effective missile launches from horseback. The enhancement of stability due to stirrups also increased the effectiveness of lance charges as well as close-quarter combat with maces, axes and swords. However, this idea could be a direct quote from Lyn White and is now discredited by experimental archaeology. There is little evidence that stirrups make any difference to lance charges since the impact pushes the rider back and out of the stirrups. At least in a European context, the feet were forwards in the charge and the cantle of the saddle was what the rider was braced against. In close quarter combat the ability to use the stirrups to stand and twist in the saddle is their major advantage. The lance use as explained in Mamluk paraphrases of earlier Muslim manuals suggest a much wider use of the

\footnotetext{
15 Consult Herrmann's (1989) detailed examination of Parthian and Sassanian equestrian technology.

16 The comment about the Marlik stirrups is meant to imply that because of the presence of Turkish officers in the late Sasanian army, the presence of stirrups in the archaeological record is does not need to be explained by a general Sassanian adoption of stirrups, but may merely be an indication of Turkish units using them. Before the Gök Türk expansion, there is no evidence that even the Soghdians used stirrups based on the wall paintings. The fact that they still used the downward pointed toe in the stirrup is an example of their artistic conservatism rather than painterly realism in the post Sassanian paintings in Panjikent.
} 
lance than just the couched lance charge referred to as the Damascus style. Changing hands and shortening and lengthening the grip could have involved a more acrobatic style of riding that would be improved by using stirrups. However, whether that was used in Sassanian times is hard to evaluate.

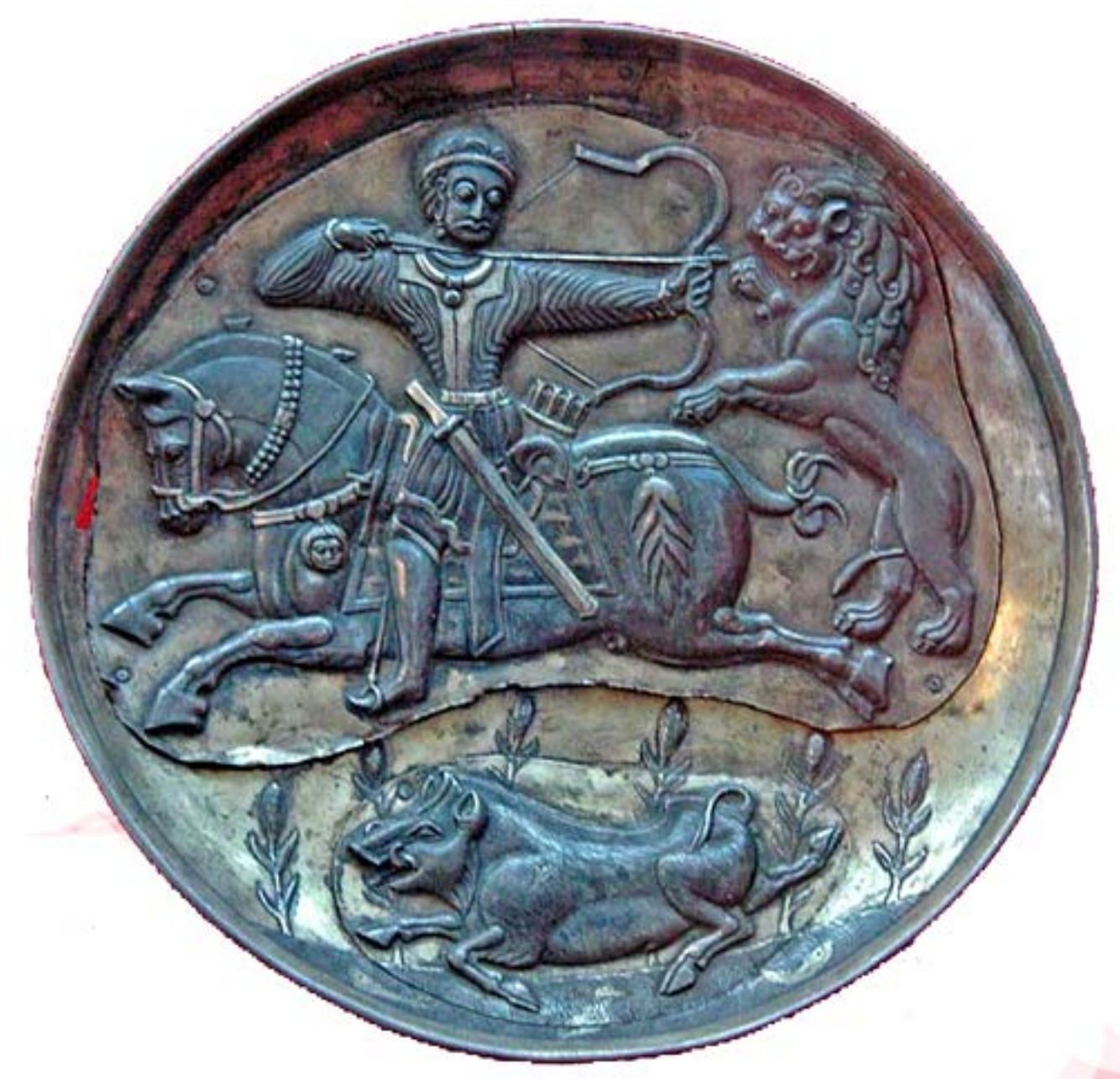

Figure 08: Post-Sassanian $\left(7^{\text {th }}\right.$ or early $8^{\text {th }}$ century CE) metalwork plate depicting Pur-e Vahman engaged in the Parthian shot against pursuing lion (Hermitage Museum, St. Petersburg, Inv.S-247).

There are two metalwork plates of the Sassanian type dated to the early post-Sassanian era of interest with respect to stirrups. The first is an $8^{\text {th }}$ century CE silver-gilt metalwork plate depicting a hunting monarch with his feet in a "stirrup-posture" (Sotheby's) (sothebys.com, 2013). While no actual stirrups are depicted in this plate, the position of the rider's feet would indicate that the artist was most likely intending to portray the rider's feet in a stirrup-like posture. The most detailed early post-Sassanian (dated to the $7^{\text {th }}$ or early $8^{\text {th }}$ centuries CE) metal work is that of Pur-e Vahman engaged in the Parthian shot against a pursuing lion (Hermitage Museum, St. Petersburg, Inv.S-247). This plate however is notable in a number of ways in its display of late Sassanian and early post-Sassanian Iranian equestrian military equipment. Note that expecting the previous two plates with possible stirrup-gear, all of the previous plates depict "traditional" early Sassanian straight and broad-style swords with the riders' feet in the "ballerina posture" without stirrups. The Pur-e Vahman metalwork plate shows the rider riding with clearly depicted stirrups much like a cavalryman depicted in a combat scene in a wall painting (reception hall VI-41) in a Soghdian palace at Panjekent.

\section{(4) Horse archery while appearing to ride backwards.}

There are two Sassanian metalwork plates depicting mounted figures shooting arrows while riding backwards. These are currently housed at the Iran Bastan Museum in Tehran and the Azerbaijan Museum in Tabriz. 


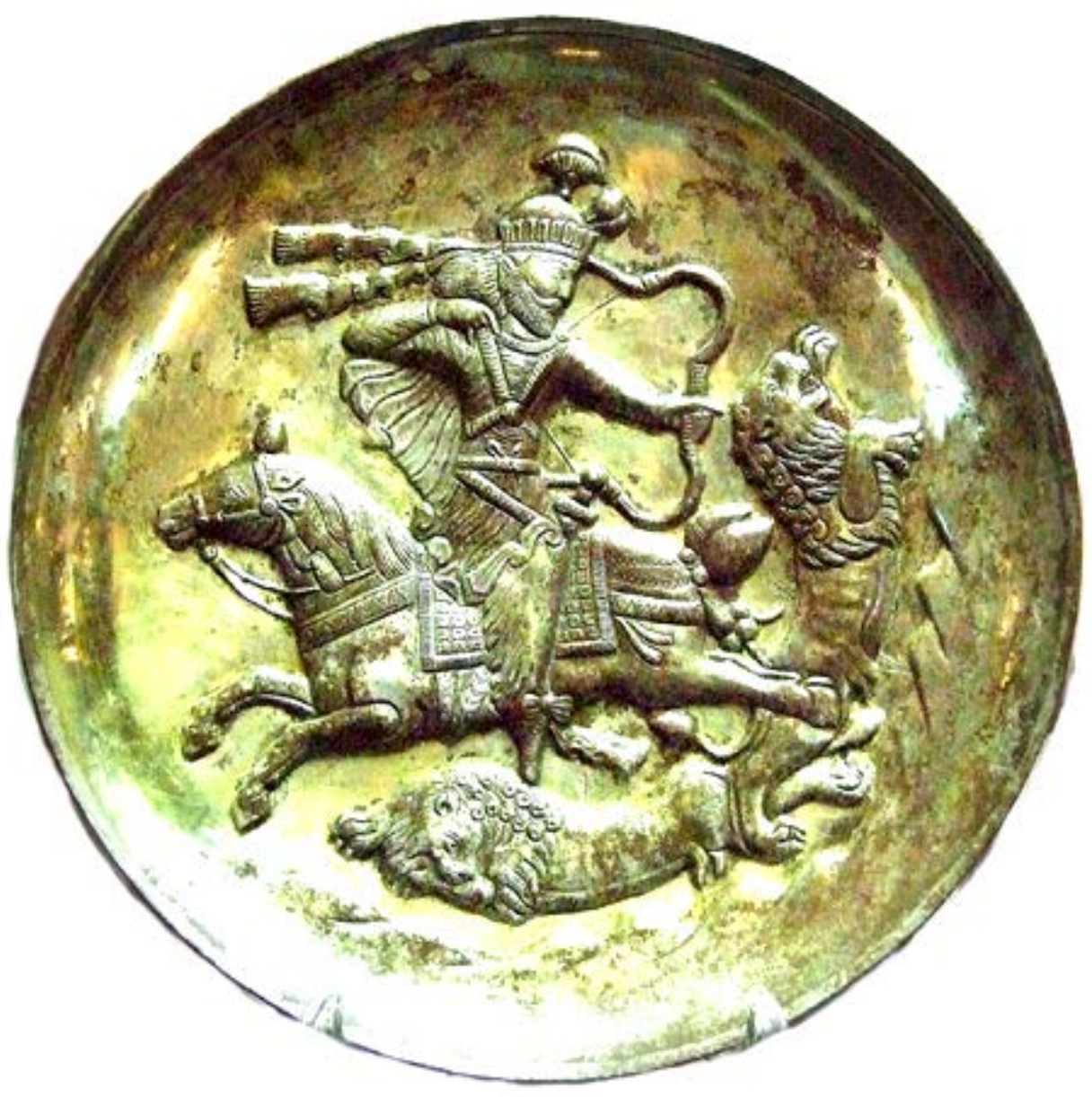

Figure 09: Sassanian silver-gold metalwork dish depicting monarch or nobleman shooting arrows while riding backwards (late $3^{\text {rd }}-4^{\text {th }}$ Century CE) (Azerbaijan Museum, Tabriz)

The question should be "Why do silversmiths show an archer shooting backwards with his leg in an awkward position?". The figure of the king is portrayed exactly as he would if the horse were facing the other direction. A standard template has been used for the king's figure rather than composing a new figure for the Parthian shot. However, in small details, adjustments have been made like putting the sword under his leg, to show his leg is meant to be turned around as he twists at the waist. Riding in a saddle without stirrups resulted in a different position of the horseman as he turned to shoot backward. The artist, working in silver, had the desire to depict this, but was able to reuse an existing design and still have the effect. This is the same position of leg as seen in the article by Katsumi Tanabe (1987, p. 82). But, this raises the question as to why the figures appear to a modern viewer to be seated backwards on their respective horses, as this posture held a negative connotation in Sassanian military culture with respect to punishment. The Sassanian Spah for example is reported as having forced General Pirouz Mehran to ride his horse backwards in front of Sassanian military personnel and nobility in a "humiliation" ceremony due to his failure at the battle of Dara against General Belisarius in 530 CE (Whitby, 1994, p. 241). If riding backwards was a standard punishment for Sassanian military personnel, this poses challenges in explaining the context of the Iran Bastan and Azerbaijan Museum plates. As the plates appear to date from the earlier Sassanian era, one possibility is that the "riding backwards" punishment ceremony may have evolved later in the history of the Sassanian military, perhaps the $6^{\text {th }}$ century $\mathrm{CE}$ as reported by Procopius with respect to General Pirouz Mehran's punishment ceremony. This assertion however requires further research for assessment and evaluation. We should note that the first figure (Sassanian King hunting lions while riding backwards, Iran Bastan Museum, Tehran) is well modeled and details like the sword hilt are well rendered as are the lions heads. This suggests it was made in one of the royal workshops. The bow is schematic and exaggerated, but the drawing hand is in perfect proportion. The arrow is sketched in and does not cross the face. The second (monarch or nobleman shooting arrows while riding backwards, Azerbaijan Museum, 
Tabriz) is much less clearly delineated. The face has smooth broad cheeks in the Turkish fashion and there is a Byzantine element to the drapery on the clothes. So too there is a Late Roman look to the sword hilt and the bowstring attaches to the base of the ears rather than the tips. The posture of the archer is collapsed, the arms out of alignment with the shoulders in a way the Sasanians and later Persians rarely showed. Most importantly the drawing hand is turned down in a way that is outside the artistic conventions of the Sassanians. It could be that provincial and based on an earlier plate. Horse archery showing a braced bow but not shooting: There is a rare plate in the Foroughi which shows a horse archer not shooting but holding a braced bow with a slight asymmetry (Ghirshman, 1959, p. 49).

\section{Comparison of Shapur II and Pur-e Vahman plates: Evolution of Sassanian cavalry.}

At first glance the plates of Shapur II (Hermitage Museum, St. Petersburg, Inv.S-253) from the $4^{\text {th }}$ century CE (earlier Sassanian era) and the early post-Sassanian plate (late 7- early $8^{\text {th }}$ centuries CE) of Pur-e Vahman (Hermitage Museum, St. Petersburg, Inv.S-247) appear similar. Both plates depict their respective figures deploying the Parthian shot against a pursuing lion. Nevertheless, despite this parallel in use of the Parthian shot between the metalwork plates, the two items diverge in three ways with respect to military technology: (1) equestrian technology, (2) weapons suspension and (3) archery techniques. The first category of equestrian technology pertains to the use of stirrups, discussed previously. Shapur's horse has no stirrups while Pur-eVahman has this technology, providing him with much greater equestrian stability than his counterpart. The second category is the manner in which weapons such as swords and archery equipment are suspended. While both figures have their swords located at the left side, Shapur II's sword is suspended with the scabbard slide system whereas Pur-e-Vahman's weapon is suspended with the locket suspension system of Central Asian origin. Pur-e Vahamn's Tirdan (quiver) is slung to his right and is presumably with the lappet system. This is highly likely as the Tirdan of the early $7^{\text {th }}$ century CE mounted armored cavalryman figure of Khosrow II inside the vault at Taq-e Bostan is suspended with the lappet suspension system. This leads into the third difference between the Shapur II and Pur-e Vahman plates: archery. While both figures draw their bows with the right hand, their manner of archery is different. While both warriors deploy the Sassanian technique of "pointing" with their index finger toward their targets, Pur-e-Vahman appears to be using the Mongolian draw technique. Interestingly excepting Pur-e Vahman, none of the plates depicting the Parthian shot show any portion of a tirdan (quiver). Pur-e Vahman's partly visible Tirdan also appears to be different in shape than the more "tubular" shaped quivers examined in previous plates depicting forward-firing horse archery.

The changes seen in military equipment seen with respect to the earlier Sassanian era (e.g. the Shapur II plate, Hermitage Museum, Inv.S-253) and the late Sassanian and/or early postSassanian era (e.g. Pur-e Vahman, Hermitage Museum, Inv.S-247) were possibly due to two factors. The first may have been due to military experiences against nomadic warriors (notably the Hephthalites in the 480s CE) along the Central Asian frontiers (Michalak, 1987, p. 83). The second factor may have had to do with the military reforms attributed to Khosrow I (r. 531-579 CE), as significant changes to military equipment certainly had appeared as evidenced for example by finds of Sassanian swords bearing the "P-mounts" for the lappet style suspension system ${ }^{17}$, the aforementioned Taq-e Bostan armored knight at Taq-e Bostan displaying the lappet suspension system for quivers as well as a new type of composite helmet (Farrokh, Karamian, \& Kubic, 2016) and the discovery of stirrups cited earlier. This was in essence a new type of knight known as the 'composite' cavalryman who entered service by the $6^{\text {th }}$ century CE (see for example analyses by Bivar, 1972; Coulston, 1986; and Farrokh \& Khorasani, 2009). This new cadre of Savaran was proficient in the use of archery equipment, lances and close quarter combat weapons such as swords, maces, and axes (Farrokh \& Khorasani, 2010, pp. 36-41).

\footnotetext{
${ }^{17}$ Examples of this technology can be seen in late Sassanian swords of the lappet-suspension type dated to late $6^{\text {th }}$ or early $7^{\text {th }}$ centuries CE in venues such as the Louvre Museum (Inv. MAO. 423, Inv. AO. 25534), the Römisches Germanisches Museum, Mainz, Germany (Inv. 037985 and Inv. 0. 379386) and the Royal Museums of Art and History in Brussels (IR. 1315).
} 


\subsection{Dromedary Archery}

A second variation of the mounted archery theme is that of a king engaged in hunting prey with arrows as he rides a camel. This is displayed by two known Sassanian metalwork plates housed at the Hermitage Museum in St. Petersburg and the Metropolitan Museum of Art in New York. Both plates show Bahram V Gur (r. 420-438 CE) riding a camel as he shoots arrows towards prey while accompanied by the diminutive figure of Azadeh. The Metropolitan plate is dated to the $5^{\text {th }}$ century CE (Accession number: 1994.402) with the Hermitage plate dated two centuries later (Inv.S-252). Despite their apparent parallels with respect to Bahram Gur shooting arrows on a dromedary platform, there is a critical difference between the Hermitage and Metropolitan plates. The Hermitage plate shows Bahram Gur with a quiver whereas the Metropolitan plate shows no quiver dangling from Bahram's side. In this case Azadeh is seen holding an arrow for Bahram to grasp as soon as he has discharged his own nocked missile (to see the influence of Bahram Gur's way of shooting and a grasp named as bahrami grasp or open grasp see Dwyer \& Khorasani, 2013, and Khorasani \& Dwyer, 2016).

Despite the metalwork display it is difficult to ascertain the military status of camels in the Sassanian Spah (army). While information on Sassanian corps is inadequate at present, some units of these may have existed, at least in the mid- $6^{\text {th }}$ century CE. Russian researchers for example cite Anoushzad, a rebel named supported by the "Imperial Camel Corps" (Pigulevskaya, 1998, p. 447) who had risen against Khosrow I (r. 531-579 CE). In practice, camel corps do not appear to have been a primary unit in the Spah and are not cited by Classical or Arabo-Islamic sources as a primary Sassanian battlefield asset. More specifically, there is little mention of camel units being deployed in battle alongside regular Sassanian units such as armored lancers, archers, infantry and battle elephants. If camels were not a primary battlefield vehicle of the Spah (army), the question is raised as to why that would have been the case. One possibility may have to do with the experience of the Parthian armies led by Ardavan V against the Roman armies of Macrinus at the 3-day Battle of Nisibis (217 CE). The Parthians were deploying camel cataphracts alongside their regular armored cavalry lancers to launch attacks into the Roman lines. The Romans however successfully counteracted the attacks of Parthian camel cataphract by rapidly deploying caltrops on the battlefield. These caused injuries to the soft spongy feet of the camels, effectively disabling them during the battle. Despite this vulnerability, camel cataphracts were potentially effective as this afforded the warrior an elevated platform to direct his archery. The hunting scene Bahram as depicted with the Hermitage certainly does not portray him as an armored cataphract, but it does provide details on archery from a camel platform. Bahram is seen with a tirdan, firing missiles with a Sassanian bow; notable is the plate's depiction of Sassanian missiles and their impact. Following the well known story, Bahram says he will convert a male animal into a female and a female into a male. He does the first by cutting off the male's horns with an arrow with a "U" shaped arrowhead and the second by shooting two arrows into the female's head as substitute horns. The two animals are shown in the center right of the plate with two arrows in the female's head and the two horns and the special arrow below the mutilated male animal. Note that the penetrative power of his missile would be multiplied in proportion to the lessening of the distance between him and his opponent. It was possible to shoot arrows in such a way as to disable or kill two opponents simultaneously, again a task contingent upon the archer`s skill. Nevertheless, there are several problematic issues with this assumption. The depiction is clearly of a story of Bahram's prowess with the bow. Any specific military interpretation is secondary to this. The artificer shows the " $U$ " shaped arrowhead clearly, one of the early depictions of this specialized equipment. In general, arrowheads in Sassanian silverwork are rather schematic. These two points, the story theme and the special arrow suggest there is little to be draw from this plate except the pedigree of the story and its theme, which is the masterful shooting of the hunter. Powerful and accurate shooting is what is being shown. Bahram's association with the Arabs is the probably reason for the camel, not a comment on Sassanian military practice. The Parthian use of camels to transport ammunition and other goods is probably their major military use outside of specifically Arab regiments raised form allies.

Yet another narrative of Bahram Gur pertains to his boyhood when he was engaged in the hunt with an Arab king named Manzar. Witnessing a lion about to slay a wild ass, Bahram shot a single arrow, killing both the lion and the wild ass (Modi, 1969, p. 180). In combat situations the 
Sassanian archer (foot or mounted) was possibly capable of targeting two men simultaneously. In such a scenario an arrow could be shot penetrating the head of an enemy infantryman and that of his comrade behind him or possibly targeting his missile in an endeavor to penetrate or even "lock" the limbs of two separate opponents.

The Hermitage S-252 and Metropolitan 1994.402 pieces are the only known Sassanian display of a camel in a martial or hunting (with archery) context. The other known Sassanian depiction of camels is seen in the right side of the grand Iwan which portrays a royal hunt scene of Khosrow II. On the upper left-hand side of the panel are five camels carrying off deer already killed by the royal hunting party. This may indicate that camels were possibly used for logistics and transportation by the Sassanians.

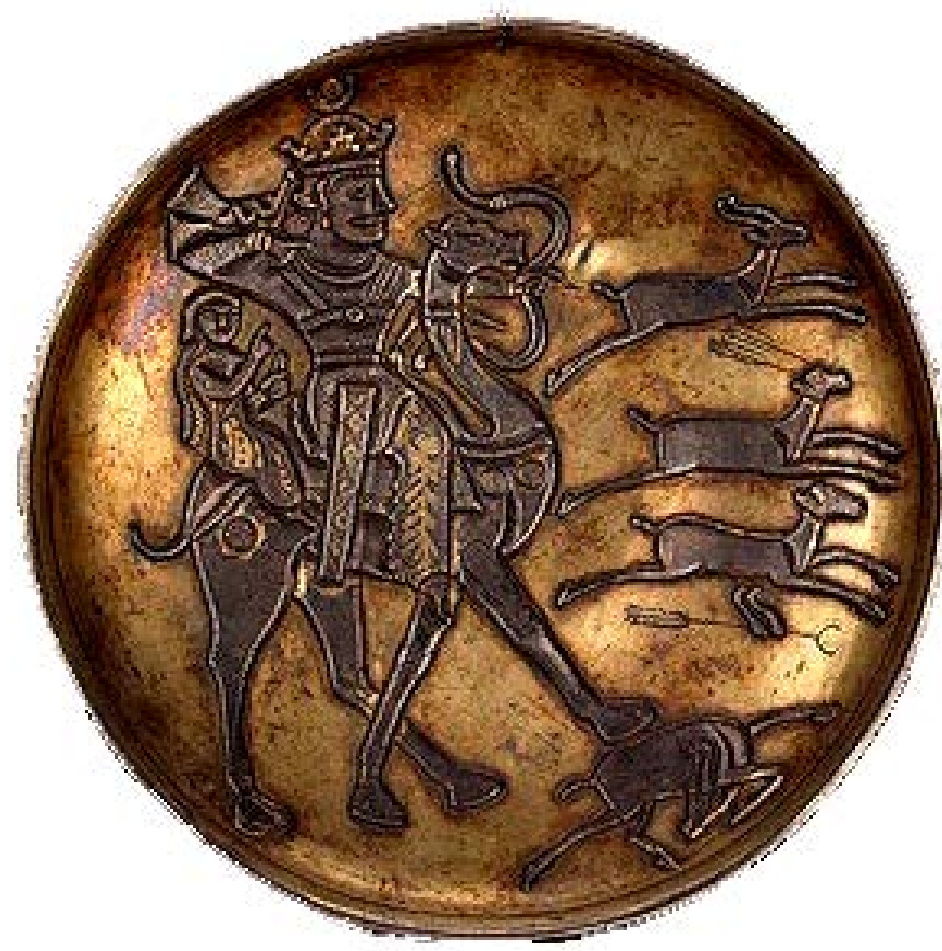

Figure 010: Sassanian metalwork plate depicting Bahram Gur hunting with his famed skills in archery; behind sits his companion Azadeh (7th Century CE) (Hermitage Museum, St. Petersburg, Inv.S-252).

The hunting motif of Bahram-Gur on camelback accompanied by Azadeh was to survive among Turkic peoples long after the Sassanian era, as seen for example in the $13^{\text {th }}$ century CE Seljuk claypaste ${ }^{18}$ bowl of Bahram Gur shooting arrows while accompanied by Azadeh (Metropolitan Museum of Art, Accession number: 57.36.13).

\subsection{Elephant Archery}

There are two known Sassanian silver metalwork plates displaying elephants. One of these is a late Sassanian plate (7th century CE) housed at the Miho Museum in Japan. Located to the right of the Miho plate, the elephant is only provided a partial display (head, trunk, tusk and frontal torso and legs only). The primary figure of the Miho plate is a regal figure on horseback engaged in the hunting of a lion and a boar (discussed further below). The rider atop the elephant appears to be in a howdah rather than a warrior as the object he points downwards towards the elephant's head appears more of tool for controlling/guiding the elephant. A second plate, also from the Sassanian era (possibly 4th-7th centuries CE), displays the elephant in the center or primary position of that plate, with a regal figure riding atop the pachyderm (LACMA-Los Angeles County Museum of Art, Gift of Nasli M. Heeramaneck, M.76.174.18). The significance of the LACMA plate is that it displays

18 The plate is stonepaste bowl is of a polychrome inglaze with overglaze painted upon an opaque monochrome glaze. 
the elephant in a combative context. This particular plate depicts Shapur II engaged in frontal archery against prey as he rides an elephant. Despite being depicted from his right side Shapur II does not appear to have any quiver suspended. This is because he is being supplied arrows by the diminished figure of a page or courtier who appears to be holding a quiver suspended to the left side of the elephant (only the top portion of that quiver is visible and is located to the rear of Shapur II). This situation has parallels with the aforementioned Bahram Gur whose arrows are supplied by Azadeh (Metropolitan Museum of Art, Accession number: 1994.402).

The Sassanians often deployed archers atop their battle elephants, which was an effective tactic given the pachyderms' exceptionally elevated platform. This allowed archers to direct their missile shot with more effectiveness against enemy cavalry and infantry as well as besieged troops in fortresses (Zoka, 1971, p. 144). According to Hekmat (1964, p. 1089), the Sassanian use of battle elephants was meant to fill same battlefield breakthrough role as scythed chariots during the Achaemenid era (Hekmat, 1964, p. 1089). But we should note that the whole subject of scythed chariots is controversial. Despite the fact that actual blades meant to have been attached to chariot axles have been found in China, this is not mentioned in the western academic literature on scythed chariots. It is assumed in the academic articles that scythed chariots were used as a method of breaking up close order infantry such as the Greeks. This assumption holds that the chariot was the missile and not a missile platform. There are so many technical problems with this view that it should be approached cautiously. That elephants could be used in a similar manner is a good point. The archers on their backs would be there to protect the elephants rather than as direct offensive warriors. However, the literature suggests that, even in the period of the Roman Republic, effective tactics for dealing with elephants were well known. Elephants seem to have been used as a sign of the strength of an army because they extraordinarily expensive to deploy. As mobile and elevated viewing platforms, they could have had a valuable use. As animate "tanks" they were an abject failure. The fact that elephants are shown in a hunting context is perhaps why they are depicted. Even in the nineteenth century in India people hunted from elephant back. The elevation and relative security from attack from all but the big cats made them an excellent mobile hunting platform. The use of elephants as visible rallying points or as psychological support for infantry is a good point made later in this section as is the use of their size and strength for siege operations. Elephants could be valuable to an army if it was well supplied enough to feed them. It is doubtful that referring to a mediaeval Armenian painting is a valid argument for how elephants were used in Sasanian times. Firdousi's interest in elephants may have been more influenced by Mahmud of Ghazni's acquisition of them than detailed surviving Sasanian military doctrine.

In practice, the Sassanians deployed elephants for the support of various battle arms. Battle elephants are believed to have been placed to the rear of front line troops, with Firdowsi 1995, p. 358) citing these as having been placed in the front lines. Elephants also provided psychological support for the infantry (Jalali, 2003, p. 17) just as these could also be used to psychologically intimidate enemy troops inexperienced in combat against these beasts (Nafisi, 1952, p. 22) ${ }^{19}$. In siege warfare, battle elephants could be used as a form of "living mobile tower" acting in concert with the Spah's inventory of siege engines for capturing enemy cities (Zoka, 1971, p. 144). Elephants were also deployed for logistical purposes, such as the transport of men and supplies to war theatres (Jalali, 2003, p. 17). A highly valued combat arm of the Sassanian Spah, the elephant corps was often deployed in battlefield situations throughout the dynasty's reign (Nafisi, 1952, p. 22), notably during the campaigns of Ardashir I (Firdowsi, 1985, p. 358) ${ }^{20}$, Shapur I (Scullard, 1974, pp. 201-202), Shapur II (Theodoret, 1985, p. 11; Ammianus, 1986, XIX, 2, p. 3), Yazdegird II (Nersessian, 2001, p. 172), Pirouz (Azari, 1972, p. 134), Khosrow I (Greatrex \& Lieu, 2002, p. 113; Procopius, 1914, VIII, 14, pp. 1-44), and Khosrow II (Greatrex \& Lieu, 2002, p. 184; Azari, 1972, p. 136) with battle elephants being present to the last years of the dynasty during the Arabo-Islamic

19 The Spah for example deployed its battle elephants against novice and untested Roman and Arabian warriors in order to affect the outcome of battles (see Jalali, 2004, p. 39).

20 According to Azari (1972, p. 132), “...after his conquests of Khorasan, Kharezam, Central Asia and Turan, Ardashir I entered northwest India and conquered the Punjab. As Ardashir advanced further he was given gifts of jewels, gold, and a large number of elephants by Junah [a local king]". More recently Charles (2007, pp. 305-306 \& 311) has disputed the role of elephants in the armies of Shapur I. 
invasions of Sassanian Iran (Masoudi, 1989, I, p .665; Tabari, XII, 2267). It is however unclear as to exactly what types of troops manned the battle elephants. Tabari (cited by Dodgeon \& Lieu, 1991, p. 285 \& Appendix I) for example states "Shapur [Shapur I], the man of the armies, rode out against them with elephants covered with blankets and with heroic fighters". It is unclear however if Tabari's citation of "heroic fighters" is referring to armored knights or archers. In practice it would appear that both armored knights and archers were utilized with battle elephants depending on the military context. In the battle of Avarayr or Vartanantz (451 CE) for example, Yazdegird II (r. 438457) deployed battle elephants against Armenian anti-Zoroastrian rebels as depicted in a medieval Armenian painting of the battle drafted by Karapet Berkretsi in 1482. The Armenian miniature displays both archers and sword armed warriors, with both types appearing to be armored. A notable parallel between the Sassanian archers depicted in the miniature that the Sassanian archers in the 15th century Armenian miniature of Karapet Berkretsi and the figure of Khosrow II in the Sassanian metalwork plate (LACMA-Los Angeles County Museum of Art, Gift of Nasli M. Heeramaneck, M.76.174.18) is that these figures are all shown as left-handed archers. The Armenian archers in the miniature however are shown as right-handed archers. Elephants were also symbols of regal splendor for the Sassanians, especially in the later Sassanian era. The regal legacy of elephants in the Sassanian era is seen for example in the designation of the New Persian term Fil (Middle Persian/Sassanian Pahlavi: Pil) ${ }^{21}$ for the position of bishop in Chess (Persian: Shatranj). Khosrow II is said to have been so fond of the elephants in his inventory that he allegedly lamented "...if only the elephant were not Indian but Iranian instead..." (Azari, 1972, p. 136). The Marvaj ol Zahab for example notes of 1000 elephants housed in Sassanian royal stables (Masoudi, 1989, I, p. 273) with the Zein ol Akhbar citing 1200 (Gardizi, 1968, p. 36). The regal status of the Sassanian elephant is illustrated at Taq-e Bostan in Western Iran where the left panel at the entranceway to the vault housing the knightly figure Khosrow II depicts the royal hunt. The (left) panel shows elephants accompanying the royal hunt entourage, with the pachyderms transporting recently hunted boars. The elephants also appear to act in concert with knights and royal trumpeters and knights in driving the pack of boars ahead of them. Unlike the metalwork plate of Khosrow II (LACMA) or the Armenian miniature of the Battle of Avarayr no archers are seen atop the elephants at the Taq-e Bostan panel.

\subsection{Arrowguide (navak)}

As we know the navak is generally used with a thumbring on the right side of the bow. The question then arises if the Sassanians had used navak, would they have still placed the device on the right side or left side of the bow. The greatest number of references to the navak are as a majra in the Arabic furusiyya literature. ${ }^{22}$ There are references that try to link the use of the majra to important Sassanian figures and to the Persians in general (Faris \& Elmer, 1945, p. 125). Some these date to the eighth century, but like accounts of the early use thumb ring they are mostly anachronistic. However, there is strong evidence of Byzantine in earlier periods. Since Maurice, who first mentioned the arrow guide as a solenarion in the West (see Nishimura, 1988), was a friend and patron of Khosrow Parviz, it is possible that Late Sasanian armies may have used the

\footnotetext{
21 The Indian term for Bishop is also Fil.

22 It might be argued that our decision not to use the so-called Arabic furusiyya literature, except when it suits our purpose, on the grounds of its supposed anachronistic nature can also be questioned even if it is clear that we are not alone in our assumptions. While the furusiyya literature was material for instruction and continuously updated, historical and other cultural literature was attempting to preserve traditional accounts. There are external sources, not relevant to this article, that show that several parts of the archery literature are unhistorical and they contradict themselves in origin stories and other ways. This is really a separate subject, but to clarify our position, it is necessary to make a few points. References to thumb ring use in early times in furusiyya manuals clearly contradict both surviving artwork and archaeology. There is a reason that the writers may have inserted such references (and probably believed them as well). Arabic literature was full of references to well-known practices being associated with famous people in the past. It was a cultural norm and in individual cases it can be evaluated when there are other sources of information. External sources, mainly Chinese and Byzantine mention the use of the arrow guide earlier than the Arabic ones and, in the case of the Chinese ones, have an internally consistent original story which also correlates with the historical appearances of arrow guides over their range.
} 
both the thumb ring and the arrow guide under the direct influence of the Gok Turks or through the medium of the Byzantines. However, this may have only been in the eastern part of the empire. The hunting scenes at Taq-e Bostan show Khosrow still shooting in the Sassanian two finger style. This could be artistic conservatism, but most of the other details are innovative, like the sword suspension and clothing which are Central Asian. In the scene of the king shooting at wild boars from a boat, the bowstring is unusually accurately indicated. The lower part of the bowstring disappears between the ring and little finger, which is slightly uncurled. The upper part of the bowstring seems displaced so that it does not obscure any part of the king's face. The arrow appears to run along the jaw and closely parallel to the line of the top of the left arm. The position of the upper part of the string indicates that a thumb draw was in use, but the position of the arrow in relation to the fist suggests a finger draw. The lower part of the bowstring ends the hand in a manner that suggests a finger draw. At best the evidence is ambiguous. The best estimate on the material suggests that the after the first wars with the Turkish Empire, the Sassanians may have started to adopt foreign ideas, but possibly only in the east. In the Sassanian heartland, the old styles of archery may have persisted. The Sassanians, if they used the arrow guide in the West, would have still used the two finger draw. A navak attached to the wrist can have been used with this draw. It can be stabilized between the thumb and index finger while the middle and ring fingers draw the string. It can be shot either way round. From Ardashir to Khosrow I, in all probability arrow guides were not used in Iran. However, Khosrow I is recorded as having received presents from the Emperor of China and the Turks were very active in the west (i.e. the west of their empire) in the $6^{\text {th }}$ century. This provided the direct opportunity for the Sassanians to acquire arrow guide technology in the second half of the $6^{\text {th }}$ century. The Sassanian military was still open to new ideas towards the end of the empire. The fourfold reorganization of the border armies was a sign of this fluidity. As in regard to the position of the arrow, the arrow can be shot on either side successfully and similarly the arrow guide can equally be used on either side. Some sources such as al-Baladhuri state that Sassanians used navak (arrowguide) at the Battle of Qadissiyah: "... Our archer would send an arrow from his Nawak bow but it would merely attach itself to an Arab`s clothes whereas their arrows would rend the mail hauberk and mail cuirass we had on" (al-Baladhuri, 1916, p. 1924).

Table 1 shows different archery techniques on Sassanian silver plates ${ }^{23}$.

${ }^{23}$ Regarding the differences in archery techniques required by different situations, it might be argued that the physical aspects of archery, namely the requirements posed by each person's anatomy (length of arms, fingers and physical strength) which influenced the way in which each person could use the bow and how he could draw it should also be analyzed in the following article. Similarly, it could be argued that the use of the different kinds of bows and different kinds of arrows for each situation and for each person (e.g. the length of the arms determined how long the arrow could be) should be discussed. Similarly, it can also be argued that the use of the different kinds of bows and different kinds of arrows for each situation and for each person (e.g. the length of the arms determined how long the arrow could be) should be discussed. We should stress that this information cannot be discerned from silver plates. One cannot estimate the height and draw length of an image created in chased metal. Draw length is a variable quantity. One can speak of a maximum draw length for an individual (i.e. one at which further drawing would be mechanically disadvantageous), but, as the manuals keep reminding us, there are several points on the body that an archer can draw an arrow giving each individual several different draw lengths. The rigid adherence to one particular draw length is a modern invention starting with Horace Ford in the nineteenth century and culminating in modern Olympic archery. This leads to misapprehension that "the length of the arms determined how long the arrow could be" whereas in fact it determines the maximum length of arrow that the archer could fully draw. In reality, archers with only arrows too long for them will not draw them fully. This may be inefficient, but it is practical. In war, it is highly unlikely that arrows were produced in many lengths and different spines (the dynamic stiffness of the arrow). It is more likely that a single arrow standard was produced and archers drew them as far and as effectively as they could. Distribution of multiple arrow lengths in battle would have been beyond even modern armies and prior to the twentieth century the concept of spine and an effective explanation of the so-called Archer's Paradox were both unknown. Oriental references at most only refer to the weight of an arrow. It is a given in a military situation that the most effective archers would be chosen for the army. Archery is a physically demanding exercise. The individual strength of an archer can be increased by practice and the gradual introduction of heavier bows into the routine. This is common to all forms of archery currently known and it would not stretch credibility to assume that the Sassanians followed a similar procedure. 
Table 1. Archery techniques on Sassanian silver plates

\begin{tabular}{|c|c|c|c|c|c|c|c|c|}
\hline $\begin{array}{c}\text { Museum } \\
\text { Original place of discovery \& dating } \\
\text { of metalwork plate }\end{array}$ & $\begin{array}{c}\text { King and/or Regal } \\
\text { Figure }\end{array}$ & Face & $\begin{array}{c}\text { Position of } \\
\text { the drawing } \\
\text { hand }\end{array}$ & $\begin{array}{c}\text { Fingers of } \\
\text { the drawing } \\
\text { hand }\end{array}$ & Bow hand & $\begin{array}{l}\text { Arrow and } \\
\text { bowstring }\end{array}$ & $\begin{array}{l}\text { Position of } \\
\text { the arrow }\end{array}$ & $\begin{array}{c}\text { Foot } \\
\text { position }\end{array}$ \\
\hline \multicolumn{9}{|c|}{ Foot archery } \\
\hline $\begin{array}{l}\text { 1. Hermitage Museum } \\
\text { Anikovskaia, Perm province, Russia; } \\
\text { dated to } 460-480 \text { CE (Trever \& } \\
\text { Lukonin, } 1987 \text { no. } 8 \text { ) }\end{array}$ & $\begin{array}{c}\text { King Pirouz } \\
\text { (r. 459-484 CE) }\end{array}$ & Profile & High & $\begin{array}{l}\text { Index finger } \\
\text { extended }\end{array}$ & $\begin{array}{l}\text { Index finger } \\
\text { extended }\end{array}$ & $\begin{array}{l}\text { Arrow not visible; } \\
\text { bowstring partially } \\
\text { visible }\end{array}$ & $\begin{array}{c}\text { Not } \\
\text { discernible }\end{array}$ & $\begin{array}{c}\text { Toes show } \\
\text { outward }\end{array}$ \\
\hline \multicolumn{9}{|c|}{ Mounted (horse, camel, elephant) archery } \\
\hline $\begin{array}{l}\text { 2. Freer and Sackler Gallery } \\
\text { Siberia, Russia; dated } 4^{\text {th }} \text { century CE } \\
\text { (Gunter \& Jett, 1992, p. 108) }\end{array}$ & $\begin{array}{c}\text { Shapur II } \\
\text { (r. 309-379 CE) }\end{array}$ & Profile & High & $\begin{array}{l}\text { Index finger } \\
\text { and small } \\
\text { finger } \\
\text { extended }\end{array}$ & $\begin{array}{l}\text { Index finger } \\
\text { extended }\end{array}$ & $\begin{array}{l}\text { Both partially } \\
\text { visible }\end{array}$ & Not visible & $\begin{array}{l}\text { Turned } \\
\text { down }\end{array}$ \\
\hline $\begin{array}{l}\text { 3. Hermitage Museum } \\
\text { Turushev, Viatka province Russia; } \\
\text { dated } 310-330 \text { CE (Trever \& Lukonin, } \\
1987 \text { no. 3) }\end{array}$ & $\begin{array}{c}\text { Shapur II } \\
\text { (r. 309-379 CE) }\end{array}$ & Profile & High & $\begin{array}{l}\text { Index finger } \\
\text { and small } \\
\text { finger } \\
\text { extended }\end{array}$ & $\begin{array}{l}\text { Index finger } \\
\text { extended }\end{array}$ & $\begin{array}{l}\text { Arrow and } \\
\text { arrowhead visible; } \\
\text { bowstring } \\
\text { depicted as one } \\
\text { string }\end{array}$ & Left side & $\begin{array}{l}\text { Turned } \\
\text { down }\end{array}$ \\
\hline $\begin{array}{l}\text { 4. Los Angeles County Museum of Art } \\
\text { (LACMA) } \\
\text { Discovery locale not cited by LACMA; } \\
\text { dated } 4^{\text {th }}-6^{\text {th }} \text { century CE } 1\end{array}$ & $\begin{array}{c}\text { Shapur II } \\
\text { (r. 309-379 CE) }\end{array}$ & Profile & High & $\begin{array}{l}\text { Index finger } \\
\text { extended }\end{array}$ & $\begin{array}{l}\text { No extension } \\
\text { of fingers }\end{array}$ & $\begin{array}{l}\text { Arrow and } \\
\text { bowstring not } \\
\text { visible }\end{array}$ & $\begin{array}{c}\text { Not } \\
\text { discernible }\end{array}$ & $\begin{array}{l}\text { Turned } \\
\text { down }\end{array}$ \\
\hline $\begin{array}{l}\text { 5. Hermitage Museum } \\
\text { Nizhniaia Shakharovskaia, Perm } \\
\text { province, Russia; dated } 4^{\text {th }} \text { century CE } \\
\text { (Trever \& Lukonin, } 1987 \text { no. } 6 \text { ) }\end{array}$ & $\begin{array}{c}\text { Shapur III } \\
\text { (r. 383-388 CE) }\end{array}$ & Profile & High & $\begin{array}{l}\text { Index finger } \\
\text { extended }\end{array}$ & $\begin{array}{l}\text { No extension } \\
\text { of fingers }\end{array}$ & $\begin{array}{l}\text { Arrow indicated } \\
\text { with a dotted line }\end{array}$ & Not visible & $\begin{array}{l}\text { Turned } \\
\text { down }\end{array}$ \\
\hline $\begin{array}{l}\text { 6. Sasanika.org } \\
\text { Discovery locale not cited by } \\
\text { Sasanika.org - private collection UK \& } \\
\text { Switzerland } 1970 \text { s- } 2005 \text { and ; dated } \\
\text { c. early } 4^{\text {th }} \text { century CE } 2\end{array}$ & $\begin{array}{c}\text { Possibly Hormizd II } \\
\text { (r. 302-309 CE) } \\
\text { when he was a } \\
\text { prince }\end{array}$ & Profile & High & $\begin{array}{l}\text { Index finger } \\
\text { extended }\end{array}$ & Not visible & $\begin{array}{l}\text { A narrow line for } \\
\text { the arrow }\end{array}$ & Not visible & $\begin{array}{l}\text { Turned } \\
\text { down }\end{array}$ \\
\hline
\end{tabular}

${ }^{1}$ Link: http://www.lacma.org/art/collection/art-ancient-near-east, accessed Feb 20, 2017.

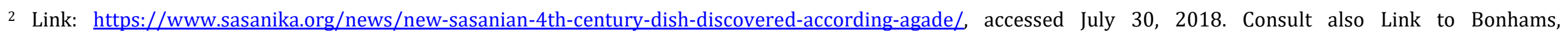
https://www.bonhams.com/auctions/21926/lot/107/, accessed July 31, 2018. 


\begin{tabular}{|c|c|c|c|c|c|c|c|c|}
\hline $\begin{array}{l}\text { 7. Iran Bastan Museum } \\
\text { Sari, northern Iran; dated } 3^{\text {rd }} \text { century } \\
\text { (Harper \& Myers, 1981, plate } 10 \text { ) }\end{array}$ & Possibly Shapur III & Profile & High & $\begin{array}{l}\text { Index finger } \\
\text { and small } \\
\text { finger } \\
\text { extended }\end{array}$ & $\begin{array}{l}\text { No extension } \\
\text { of fingers }\end{array}$ & $\begin{array}{l}\text { Arrow clearly } \\
\text { visible; bowstring } \\
\text { partially visible }\end{array}$ & Left side & $\begin{array}{l}\text { Turned } \\
\text { down }\end{array}$ \\
\hline $\begin{array}{l}\text { 8. Azerbaijan Museum, Tabriz } \\
\text { East Azerbaijan province, Iran; Dated } \\
\text { late } 3^{\text {rd }} 4^{\text {th }} \text { century }{ }^{3}\end{array}$ & $\begin{array}{l}\text { Unidentified regal } \\
\text { figure }\end{array}$ & Profile & High & $\begin{array}{l}\text { Index finger } \\
\text { and small } \\
\text { finger } \\
\text { extended }\end{array}$ & $\begin{array}{l}\text { Index finger } \\
\text { extended }\end{array}$ & $\begin{array}{l}\text { Arrow not visible; } \\
\text { bowstring partially } \\
\text { visible }\end{array}$ & $\begin{array}{c}\text { Not } \\
\text { discernible }\end{array}$ & $\begin{array}{l}\text { Turned } \\
\text { down }\end{array}$ \\
\hline $\begin{array}{l}\text { 9. Arthur Sackler Gallery } \\
\text { Iran, specific locale undetermined; } \\
\text { dated } 4^{\text {th }}-5^{\text {th }} \text { century (Gunter \& Jett, } \\
1992, \text { p.27) }\end{array}$ & $\begin{array}{l}\text { Unidentified regal } \\
\text { figure }\end{array}$ & Profile & High & $\begin{array}{l}\text { Index finger } \\
\text { extended }\end{array}$ & $\begin{array}{l}\text { Index finger } \\
\text { extended }\end{array}$ & $\begin{array}{l}\text { Bowstring } \\
\text { invisible; arrow } \\
\text { partially visible }\end{array}$ & Not visible & $\begin{array}{l}\text { Turned } \\
\text { down }\end{array}$ \\
\hline $\begin{array}{l}\text { 10. MET } \\
\text { Iran, specific locale undetermined; } \\
\text { dated c. } 5^{\text {th }} \text { century } 4\end{array}$ & $\begin{array}{l}\text { Bahram Gur } \\
\text { accompanied by } \\
\text { Azadeh }\end{array}$ & $\begin{array}{l}\text { Half } \\
\text { way }\end{array}$ & High & $\begin{array}{l}\text { Index finger } \\
\text { extended }\end{array}$ & $\begin{array}{l}\text { Index finger } \\
\text { extended }\end{array}$ & $\begin{array}{l}\text { Arrow clearly } \\
\text { visible; bowstring } \\
\text { partially visible }\end{array}$ & Right side & $\begin{array}{l}\text { Turned } \\
\text { down }\end{array}$ \\
\hline $\begin{array}{l}\text { 11. MET } \\
\text { Qazvin, Iran; dated late } 5^{\text {th }}-\text { early } 6^{\text {th } 5}\end{array}$ & $\begin{array}{l}\text { Identity uncertain, } \\
\text { may be either Peroz } \\
\text { (r. 459-484 CE) or } \\
\text { Kavad I (r. 488-497 } \\
\text { CE, 499-531 CE) }\end{array}$ & Profile & High & $\begin{array}{l}\text { Index finger } \\
\text { and small } \\
\text { finger } \\
\text { extended }\end{array}$ & $\begin{array}{l}\text { Index finger } \\
\text { extended }\end{array}$ & Arrowhead visible & Not visible & $\begin{array}{l}\text { Turned } \\
\text { down }\end{array}$ \\
\hline $\begin{array}{l}\text { 12. Sotheby's } \\
\text { Iran, specific locale undetermined; } \\
\text { dated } 5-6^{\text {th }} \text { centuries }{ }^{6}\end{array}$ & $\begin{array}{l}\text { Unidentified regal } \\
\text { figure }\end{array}$ & Profile & High & $\begin{array}{l}\text { Index finger } \\
\text { extended }\end{array}$ & $\begin{array}{l}\text { No extension } \\
\text { of fingers }\end{array}$ & $\begin{array}{l}\text { Arrow and } \\
\text { bowstring visible } \\
\text { and shown as a } \\
\text { line }\end{array}$ & $\begin{array}{c}\text { Not } \\
\text { discernible }\end{array}$ & $\begin{array}{l}\text { Turned } \\
\text { down }\end{array}$ \\
\hline $\begin{array}{l}\text { 13. Los Angeles County Museum of Art } \\
\text { (LACMA) } \\
\text { Iran, specific locale undetermined; } \\
\text { dated } 4^{\text {th }} \text { or } 6^{\text {th }}-7^{\text {th }} \text { (Mousavi, 2012) } 7\end{array}$ & $\begin{array}{l}\text { Unidentified regal } \\
\text { figure }\end{array}$ & Profile & High & $\begin{array}{l}\text { Index finger } \\
\text { extended }\end{array}$ & Not visible & $\begin{array}{l}\text { Arrow not visible; } \\
\text { bowstring partially } \\
\text { visible }\end{array}$ & Not visible & $\begin{array}{c}\text { Turned } \\
\text { down }\end{array}$ \\
\hline $\begin{array}{l}\text { 14. Cleveland Museum of Art } \\
\text { Iran, specific locale undetermined; } \\
\text { dated } 5^{\text {th }}-7^{\text {th }} \text { centuries } C E^{8}\end{array}$ & $\begin{array}{l}\text { Hormizd II (r. 302- } \\
309 \text { CE) or Hormizd } \\
\text { III (r. 457-459 CE) }\end{array}$ & Profile & High & $\begin{array}{l}\text { Index finger } \\
\text { extended }\end{array}$ & $\begin{array}{c}\text { No extension } \\
\text { of fingers }\end{array}$ & $\begin{array}{c}\text { Arrow and } \\
\text { bowstring partially } \\
\text { visible }\end{array}$ & Not visible & $\begin{array}{c}\text { Turned } \\
\text { down }\end{array}$ \\
\hline
\end{tabular}

${ }^{3}$ Link: http://apollon.blog.bg/izkustvo/2011/09/12/zlatoto-na-drevna-persiia-skitiia-sarmatiia-krit-i-hetiia.818378, accessed Feb 10, 2017.

${ }^{4}$ Link: https://www.metmuseum.org/art/collection/search/327497, accessed January 12, 2017.

${ }^{5}$ Link: https://www.metmuseum.org/art/collection/search/322973, accessed August 3, 2018.

${ }^{6}$ Link: http://www.thecityreview.com/f00sant.html, accessed Feb 19, 2017.

${ }^{7}$ Link: https://collections.lacma.org/node/198847 


\begin{tabular}{|c|c|c|c|c|c|c|c|c|}
\hline $\begin{array}{l}\text { 15. Hermitage St. Petersburg } \\
\text { Perm province, Russia; dated 6-7th } \\
\text { centuries (Trever \& Lukonin, 1987 no. } \\
\text { 6) }\end{array}$ & $\begin{array}{l}\text { Shapur III } \\
\text { (r. 383-388) }\end{array}$ & Profile & High & $\begin{array}{l}\text { Index finger } \\
\text { extended }\end{array}$ & $\begin{array}{l}\text { No extension } \\
\text { of fingers }\end{array}$ & $\begin{array}{l}\text { Arrow not visible; } \\
\text { bowstring partially } \\
\text { visible }\end{array}$ & $\begin{array}{c}\text { Not } \\
\text { discernible }\end{array}$ & $\begin{array}{l}\text { Turned } \\
\text { down }\end{array}$ \\
\hline $\begin{array}{l}\text { 16. Arthur M. Sackler Gallery } \\
\text { Iran, specific locale undetermined; } \\
\text { dated 7th century (Gunter \& Jett, } \\
\text { 1992, p.27) }\end{array}$ & $\begin{array}{l}\text { Unidentified regal } \\
\text { figure }\end{array}$ & Profile & High & $\begin{array}{l}\text { Index finger } \\
\text { extended }\end{array}$ & $\begin{array}{l}\text { No extension } \\
\text { of fingers }\end{array}$ & $\begin{array}{l}\text { Arrow and } \\
\text { bowstring not } \\
\text { visible }\end{array}$ & Not visible & $\begin{array}{l}\text { Turned } \\
\text { down }\end{array}$ \\
\hline $\begin{array}{l}\text { 17. Bibliotheque Nationale, Paris } \\
\text { Iran, specific locale undetermined; } \\
\text { dated } 7^{\text {th }} \text { century (Ghirshman, 1951, } \\
\text { pl.XV) }\end{array}$ & $\begin{array}{l}\text { Yazdegerd III } \\
\text { (r. 632-651) }\end{array}$ & Profile & High & $\begin{array}{l}\text { Index finger } \\
\text { extended }\end{array}$ & $\begin{array}{l}\text { Index finger } \\
\text { extended }\end{array}$ & $\begin{array}{l}\text { Arrow and } \\
\text { bowstring partially } \\
\text { visible }\end{array}$ & Not visible & $\begin{array}{l}\text { Turned } \\
\text { down }\end{array}$ \\
\hline $\begin{array}{l}\text { 18. Hermitage Museum } \\
\text { Perm province, Russia; dated early } \\
\text { 7th century (Trever \& Lukonin, } 1987 \\
\text { no. 11) }\end{array}$ & $\begin{array}{c}\text { Khosrow II } \\
\text { (r. 590, 591-628 CE) }\end{array}$ & Profile & High & $\begin{array}{l}\text { Index finger } \\
\text { and small } \\
\text { finger } \\
\text { extended }\end{array}$ & $\begin{array}{l}\text { Index finger } \\
\text { extended }\end{array}$ & $\begin{array}{l}\text { Arrow clearly } \\
\text { visible; bowstring } \\
\text { partially visible }\end{array}$ & Left side & $\begin{array}{l}\text { Turned } \\
\text { down }\end{array}$ \\
\hline $\begin{array}{l}\text { 19. Hermitage Museum } \\
\text { Ufa (Republic of Bashkortostan), } \\
\text { Russia; dated early-mid } 7^{\text {th }} \text { century } \\
\text { (Trever \& Lukonin, } 1987 \text { no. } 10 \text { ) }\end{array}$ & $\begin{array}{l}\text { Unidentified regal } \\
\text { figure }\end{array}$ & Profile & High & $\begin{array}{l}\text { Index finger } \\
\text { extended }\end{array}$ & $\begin{array}{l}\text { Index finger } \\
\text { extended }\end{array}$ & $\begin{array}{l}\text { Arrow and } \\
\text { bowstring partially } \\
\text { visible }\end{array}$ & $\begin{array}{c}\text { Not } \\
\text { discernable }\end{array}$ & $\begin{array}{l}\text { Turned } \\
\text { down }\end{array}$ \\
\hline $\begin{array}{l}\text { 20. Hermitage Museum } \\
\text { Perm region, Russia; Dated } 7^{\text {th }} \\
\text { century (Trever \& Lukonin, } 1987 \text { no. } \\
\text { 9) }\end{array}$ & $\begin{array}{c}\text { Khosrow I } \\
\text { (r.531-579 CE) }\end{array}$ & Frontal & Low & $\begin{array}{l}\text { Index finger } \\
\text { extended }\end{array}$ & $\begin{array}{l}\text { Index finger } \\
\text { extended }\end{array}$ & $\begin{array}{c}\text { Arrow and } \\
\text { bowstring visible }\end{array}$ & right side & Halfway \\
\hline $\begin{array}{l}\text { 21. Hermitage Museum } \\
\text { Central Asia, Soghdia region; dated } 7^{\text {th }} \\
\text { or early } 8^{\text {th }} \text { century (Trever \& } \\
\text { Lukonin, } 1987 \text { no. } 17 \text { ) }\end{array}$ & $\begin{array}{l}\text { Unidentified regal } \\
\text { figure, possibly Pur- } \\
\text { e Vahman }\end{array}$ & Frontal & Low & $\begin{array}{l}\text { Index finger } \\
\text { curled over } \\
\text { the thumb }\end{array}$ & $\begin{array}{l}\text { Index finger } \\
\text { extended }\end{array}$ & $\begin{array}{c}\text { Arrow and } \\
\text { bowstring visible }\end{array}$ & Right side & $\begin{array}{l}\text { Stirrups } \\
\text { clearly } \\
\text { shown }\end{array}$ \\
\hline $\begin{array}{l}\text { 22. Sotheby's } \\
\text { Iran, specific locale undetermined; } \\
\text { dated Post-Sassanian } 8^{\text {th }} \text { century }{ }^{9}\end{array}$ & $\begin{array}{l}\text { Unidentified regal } \\
\text { figure }\end{array}$ & Frontal & Low & $\begin{array}{l}\text { Index finger } \\
\text { extended }\end{array}$ & $\begin{array}{l}\text { No extension } \\
\text { of fingers }\end{array}$ & $\begin{array}{l}\text { Arrow visible; } \\
\text { bowstring partially } \\
\text { visible }\end{array}$ & right side & $\begin{array}{l}\text { Feet in } \\
\text { stirrup } \\
\text { posture } \\
\text { (horizontal) }\end{array}$ \\
\hline
\end{tabular}

8

http://www clevelandart org/art/1962 150?collection search views fullext=\&created date op $=\% 3 \mathrm{D} \& \mathrm{created}$ date $=\&$ between start=\&between end=\&field artist=8 e=1\&f\%5B0\%5D=field collection:825, accessed Feb 18, 2017.

${ }^{9}$ Link: http://www.sothebys.com/en/auctions/ecatalogue/2013/arts-of-the-islamic-world-l13220/lot.115.html, accessed Feb 11, 2017. 


\section{Conclusion}

Sassanian silver plates make a solid contribution to the understanding of Sassanian archery techniques. They increase the understanding of archery techniques that were during the early and late periods of the empire as well as some post-Sassanian silver plates. Sassanian plates show foot archery and mounted archery. The latter contains horse archery, dromedary archery and elephant archery. In spite of artistic conventions and the related limitations of Sassanian silver plates, one can discern many techniques such as grasping the bow grip, drawing the bow and the location of where to place the arrow.

Sassanian archery was distinct and consistent in its unique approach. By the end of the empire new influences came from the east and spread the thumb draw in the empire. Even some Persian and Arab manuals mention of archery methods used by Sassanian kings. In spite of their artistic conventions and limitations, Sassanian silver plates provide some useful information on Sassanian archery techniques. Future findings and research will shed more information on the topic.

\section{References}

Primary References

Al-Baladhuri (1924). The Origins of the Islamic State. Translated by. P.K. Hitti and F.C. Murgotten. London: P. S. King \& Son.

Ammianus, M. (1996). The later Roman Empire. London: Penguin Books.

Dennis, G. T. (Trans.). (1984). Maurice's Strategikon. Pennsylvania: University of Pennsylvania Press.

Farrokhi-Sistani, H. (1957). Divan-e Farrokhi-Sistani. Edited by M. Dabirsiaqi. Tehran: Eqbal.

Firdowsi. (1995). Shahname. Persian version (edited and compiled by M.A. Foroughi, including Mohl's version of edits translated into Persian). Tehran: Entesharate Javidan.

Gardizi, A. (1968). Zein ol Akhbar History. (Abdolhay Habibi revision). Tehran: Iran Cultural Foundation

Herodian (1970). History of the Empire. Translated by C. R. Whittaker. Cambridge, MA: Harvard University Press.

Herodotus (1972). The Histories. Translated by A. Selincourt. London: Penguin Books.

Khordeh Avesta comprising Ashem, Yatha, the Five Nyaeshes, the Five Gehs, Vispa Humata, Namsetaeshne, patet-Avesa, patet Pashemanee, all the Nirangs, Bajs and namaskars, fifteen Yashts, the Afringans, the Afrins, and the Ashirvad (1936). Edited by Navroji Pestonji Kavasji Kanga, Bombay: Jenaz Printers.

Masoudi (Al-), A. al H. (1989). Muruj al Dhahab wa ma'adin al-Jawahir. Translated and edited by P. Lunde and C. Stone. London: Kegan Paul International, 1989.

Menog e Xrad, Danak-u Mainyo Xard, Pahlavi, Pazand, and Sanskrit. (1913). Edited by T. D. Anklesaria. Bombay: T. D. Anklesaria.

Moezzi, A. A. M. (1940). Divan-e Ash'ar. Edited by A. Eqbal. Tehran: Entesharate Islamiyeh.

Procopius of Caesarea. (1914). History of the Wars. Books I \& II. Translated by H.B. Dewing, Cambridge: Harvard University Press.

Saad-Salman, M. (1961). Divan-e Saad-Salman. Edited by R. Yasemi. Tehran: Pirouzi.

Strabo (1960). Geography. Translated and edited by H. L. Jones. London: William Heinemann.

Tabari, Abu Jaafar Mohammad bin Jarir, Tarikh al Rasl ol Molook, edited by M.J. De Goeje (15 volumes), Leiden: E. J. Brill, 1879-1901.

Theodoret (1985). Historia Religiosa I. Partly translated by R. M. Price. Kalamazoo, Michigan: Cistercian Publications.

\section{Secondary References}

Akhavan-Aghdam N. (2014). Tafsire shamāyele negārāneye sahnehāye shekār dar zoruf-e feleziye sāssāni [Analysis of the imagery of hunting scenes in Sassanian metalwork plates]. Faslnameye Kimiā-iye Honar, 3(12), 33-50. 
Allsen, T. T. (2006). The Royal Hunt in Eurasian History. Philadelphia: University of Pennsylvania Press.

Azari, A. (1972). Nagshe Fil dar Janghaye Iran Bastan [The role of battle elephants in Ancient Iran]. Baresihaye Tarikhi, 1, 127-142.

Bivar, A.D.H. (1972). Cavalry equipment and tactics on the Euphrates frontier. Dumberton Oak Papers, 26, 273-291.

Bosworth, C. E. (1987, December 15). Asāwera. Retrieved from Encyclopaedia Iranica: http://www.iranicaonline.org/articles/asawera-arabic-broken-plural-form-the-variantasawirat-also-occurs-in-yaqubi-p

Chang, K. (Ed.). (1986). Studies in Shang Archaeology. New Haven, Conn: Yale University Press.

Charles, M.B. (2007). The rise of the Sassanian Elephant Corps: Elephants and the later Roman Empire. Iranica Antiqua, XLII, 301-346. doi: 10.2143/IA.42.0.2017880

Coulston, J. C. (1985). Roman Archery Equipment. In M. C. Bishop (Ed.), The Production and Distribution of Roman Military Equipment. Proceedings of the Second Roman Military Equipment Seminar (pp. 220-366). British Archaeological Reports.

Coulston, J.C. (1986). Roman, Parthian and Sassanid tactical developments, In P. Freeman and D. Kennedy (eds), The Defense of the Roman and Byzantine East (pp. 59-75). Oxford: British Institute of Archaeology at Ankara.

de la Broquière, B. (1988). The Voyage d'Outremer. (G. R. Kline, Trans.) New York: Peter Lang.

Dodgeon, M.H. \& Lieu, S.N.C. (1991). The Roman Eastern Frontier and the Persian Wars (AD 226363). London \& New York: Routledge.

Dwyer, B., \& Moshtagh Khorasani, M. (2013). An Analysis of a Persian Archery manuscript written by Kapur Čand. Revista de Artes Marciales Asiáticas, 8(1), 1-12. doi: 10.18002/rama.v8i1.797

Elliott, M. C. (2001). The Manchu Way. Stanford: Stanford University Press.

Emory, W. B. (1967). Lost Land Emerging. New York: Charles Scribner's Sons.

Erdelyi, I. (1966). The Art of the Avars. Corvina Press

Faris, N. A., \& Elmer, R. P. (1945). Arab Archery. Princeton: Princeton University Press.

Farrokh, K. (2009). The Winged Lion of Meskheti: a pre- or post-Islamic Iranian Legacy in Georgia? In Scientific Paradigms. Studies in Honour of Professor Natela Vachnadze (pp. 455-492). Tbilisi: St. Andrew the First-Called Georgian University of the Patriarchy of Georgia.

Farrokh, K. \& Khorasani, M.M. (2009). Arms, Armor and Tactics of Sassanian Savaran. Journal of the Iranian Studies, 8(15), 288-305.

Farrokh, K. \& Khorasani, M.M. (2010). Backbone of the Empire: Sassanian Savaran. Classic Arms and Militaria, XVII(1), 36-41.

Farrokh, K., Karamian, Gh., \& Kubic, A. (2016). An Examination of Parthian and Sassanian Military Helmets 2nd century BCE - 7th century CE (2016). The Third Colloquia Baltica-Iranica, Nov 25-26, Siedlce University.

Ghirshman, R. (1951). L'Iran des Origines à l'Islam. Paris: Payot.

Ghirshman, R. (1959). Une Coupe sassanide à scène de chasse, de la Collection M. Foroughi, Artibus Asiae, 22(1/2), 48-52.

Ghirshman, R. (1962). Iran Parthians and Sassanians. (G. Stuart, \& J. Emmons, Trans.) France: Thames and Hudson.

Greatrex, G., \& Lieu, S. N. C. (2002). The Roman Eastern Frontier and the Persian Wars Part II (AD 363-630). London \& New York: Routledge.

Gunter, A.C., \& Jett, P.J. (1992). Ancient Iranian Metalwork in the Arthur M. Sackler Gallery and the Freer Gallery of Art. Washington D.C.: Smithsonian Institution.

Hanaway Jr., W.L. (1971). The concept of the hunt in Persian literature. Boston Museum Bulletin, 69(355/356), 21-69.

Harper, P.O., \& Myers, P. (1981). Silver vessels of the Sassanian Period Volume: Royal Imagery. New York: The Metropolitan Museum of Art.

Hekmat, A. A. (1964). Iranshahr-Jeld e Dovom [The Iranian Realm-Volume II]. Tehran: 22 nd Publication of the National UNESCO Commission of Iran.

Herrmann, G. (1977). The Iranian Revival. Oxford: Elsevier-Phaidon.

Herrmann, G. (1989). Parthian and Sassanian saddlery: New Light from the Roman West. In L. De Meyer and E. Haerinck (eds), Atchaeologia Iranica et Orientalis: Miscellania in Honorem Louis Vanden Berge (pp. 757-809). Gent: Peeters Publishers. 
Inostrancev, C. A. (1926). The Sassanian military theory (Translated by L. Bogdanov). The Journal of the CAMA Oriental Institute, 7, 7-52.

Inostrancev, C. A. (1969). Sasanidskie et'udy. Translated to Persian by Kazem Kazemzadeh as Motaleati Darbaraye Sassanian [Studies regarding the Sassanians]. Tehran: Bongahe Tarjome va Nashre Ketab.

Jalali, I. (2003), Artesh, Tashkeelat va Vahedhaye an dar Asr e Sassanian [The Army, Composition and Units in the Sassanian Era]'. Reshteye Amoozesh e Tarikh, (13), 12-20.

Jandora, J.W. (2010). Archers of Islam: A Search for 'Lost' History. The Medieval History Journal, 13(1), 97-114. doi: 10.1177/097194580901300104

Karantabias, M.A. (2005). The crucial development of heavy cavalry under Herakleios and his usage of steppe nomad tactics. Hirundo: The McGill Journal of Classical Studies, IV, 28-41.

Khorasani, M., \& Dwyer, B. (2016). A Persian archery manual by Mohammad Zaman. Revista de Artes Marciales Asiáticas, 11(1), 48-65. doi: 10.18002/rama.v11i1.3708

Khorasani, M. (2012). The sacred weapon: bow and arrow combat in Iran. Revista de Artes Marciales Asiáticas, 5(1), 53-76. doi: 10.18002/rama.v5i1.124

Latham, J. D., \& Paterson, W. F. (1970). Saracen Archery. London: The Holland Press

Matofi, A. (1999). Tarikh-e-Chahar Hezar Sal-e Artesh-e Iran: Az Tamadon-e Elam ta 1320 Khorsheedi, Jang-e- Iran va Araqh [The 4000 Year History of the Army of Iran: From the Elamite Civilization to 1941, the Iran-Iraq War]. Tehran: Entesharat-e Iman.

Michalak, M. (1987). The origins and development of Sassanian heavy cavalry. Folia Orientalia, 24, 73-86.

Modi, J. J. (1969). Archery in ancient Persia: a few extraordinary feats. Bombay Branch of the Royal Asiatic Society Journal, XXV, 175-186.

Mousavi, A. (2012). Ancient Near Eastern art at the Los Angeles County Museum of Art. Los Angeles: Los Angeles County Museum of Art.

Nafisi, S. (1952). Tarikhe Tamadon e Sassani [The History of Sassanian Civilization]. Tehran: Entesharate Daneshgahe Tehran.

Nersessian, V. (2001). Treasures from the Ark: 1700 years of Armenian Christian Art. London: The British Library.

Nicolle, D. (2005). Rome's Enemies: The Desert Frontier. Oxford: Osprey Publishing Men at Arms Series.

Nishimura, D. (1988). Arrow-Guides and the "Solenarion". Byzantion, 58(2), 422-435.

Overlaet, B. (1998). Regalia of the Ruling Classes in Late Sasanian Times: The Riggisberg Strap Mountings, Swords and Archer's Fingercaps. Riggisberger Berichte , 267-297.

Pigulevskaya, N. (1998). Shahrhaye Iran dar Roozegare Partian va Sassanian [The Cities of Iran during the Parthian and Sassanian Eras]. Translated into Persian by E. Reza. Tehran: Entesharat-e Elmi va Farhangi.

Pope, S. (1918). Yahi Archery. University of California publications in American archaeology and ethnology, 13(3), 103-153.

Sasanika.org. (2014, April 16). New Sasanian 4th Century Dish Discovered - According to Agade. Retrieved from http://www.sasanika.org/news/new-sasanian-4th-century-dish-discoveredaccording-agade (accessed: Feb 1, 2017).

Scullard, H.H. (1974). The Elephant in the Greek and Roman World. Ithaca, New York: Cornell University Press.

Selby, S. (2000). Chinese Archery. Hong Kong: Hong Kong University Press.

Sinor, D. (Ed.). (1990). The Cambridge History of Early Inner Asia. Cambridge: Cambridge University Press.

Skupniewicz. P. (2015). Tabriz Museum battle dish: formal considerations. Metamorphoses of History, 6, 180-211.

Sothebys.com. (2013, April 24). An important post-Sasanian silver-gilt footed dish, Persia, 8th Century. Retrieved from http://www.sothebys.com/en/auctions/ecatalogue/2013/arts-ofthe-islamic-world-113220/lot.115.html (Accessed: Feb 11, 2017).

Stein, E. (1949). Histoire du Bas-Empire. Paris, Brussels, Amsterdam: Desclee de Brouter.

Swoboda, A. (2015). Sztuka posługiwania się łukiem refleksyjnym (II ed.). Poland: Adam Swoboda.

Tafazzoli, A. (1993). A list of terms for weapons and armour in Western Middle Iranian. Silk Road Art and Archeology, 3, 187-198. 
Tanabe, K. (1987). A Sasanian Silver Plate with a Leopard Hunt. Bulletin of the Asia Institute, 1, 8194.

Trever, K.V., \& Lukonin, V.G. (1987). Sasanidskoe serebro. Khudozhestvennaia kul'tura Irana III-VIII vekov. Sobranie Gosudarstvennogo Ermitazha [Sasanid silver. Artistic culture of Iran III-VIII centuries. Collection of the State Hermitage Museum]. Moscow: Iskusstvo.

Whitby, M. (1994). The Persian king at War. In E. Dabrowa (Ed.), The Roman and Byzantine Army in the East. Proceedings of a Colloquium held at the Jagiellonian University, September, 1992, Krakow, pp.227-263.

Yasinzadeh, H., Moussavi-Koohpar, S.M., \& Afhami, R. (2013). Motale-eh va baresiye osul-e tarkibbandi dar bošqābhāye šekār-e Sāssāni [The study and analysis of the principles of compostion in Sassanian hunting plates]. Našriyeye Honarhaye Zibā-Honarhāye Tajasomi, 18(1), 25-32.

Zakeri, M. (1995). Sasanid Soldiers in Early Muslim Society: The Origins of Ayyārān and Futuwwa. Wiesbaden: Harrassowitz Verlag.

Zoka, Y. (1971). Arteshe Shahanshahi e Iran az Khourosh ta Pahlavi [The Imperial Army Iran from Cyrus to Pahlavi]. Tehran: Chapkhaneye Vezarate Farhang va Honar.

\section{Author's biographical data}

Dr. Kaveh Farrokh (Canada) is a lecturer and reader of History at the University of British Columbia Continuing Studies Division; Member of Academic Board and Faculty Member for the Institute of Historical Iranian Studies; Head of Department of Traditions \& Cultural History of WAALM School of Cultural Diplomacy (nominated for Nobel Peace Prize, 2011) affiliated with Academic Council on United Nations System (ACUNS) \& International Peace Bureau; Member of Stanford University WAIS (World Association of International Studies); Member of Hellenic-Iranian Studies. He is an active research member of Razmafzar Organization. Email:manuvera@aol.com

Dr. Manouchehr Moshtagh Khorasani (Germany) is a lecturer and professor of business ethics and intercultural management at Frankfurt School of Finance and Management and ISM (International School of Management in Frankfurt) at MBA and Master Degree levels; Dr. Khorasani has written six books and published five books and is the award-winning author who won the prestigious awards of the Book Prize of the Islamic Republic of Iran in 2012 for his book Lexicon of Arms and Armor from Iran: A Study of Symbols and Terminology and the Book Prize of the Islamic Republic of Iran in 2009 for his book Arms and Armor from Iran: The Bronze Age to the End of the Qajar Period. He has also written 168 print articles (more than 100 in peer review journals worldwide). $\mathrm{He}$ is the founder of Razmafzar Organization. E-mail: manouchehr@moshtaghkhorasani.com

Bede Dwyer (Australia) has pursued his interest in oriental archery for approximately 36 years of his adult life. In that time, he has researched the archery traditions of Iran, Northern India, Turkey, Mamluk Egypt, Mongolia, China and Korea. Rather than just compile information from old books, Bede has actively tested equipment and techniques and makes archers' rings, arrows, quivers and bow cases. He is an active member of Razmafzar Organization dedicated to the study and academic research on historical Persian arms and armor and martial arts. E-mail: bededw@tpg.com.au 